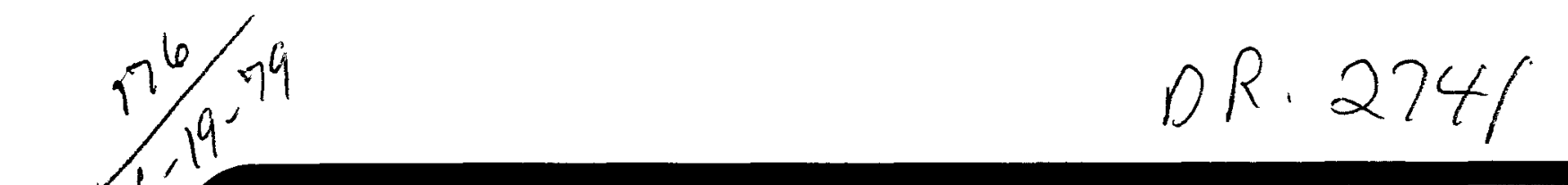

GA-A15262

UC-77

\title{
MASTER
}

\section{HTGR SPENT FUEL STORAGE STUDY}

by

R. M. BURGOYNE and N. D. HOLDER

Prepared under

Contract EY-76-C-03-0167

Project Agreement No. 53

for the San Francisco Operations Office

Department of Energy

DATE PUBLISHED: APRIL 1979 


\section{NOTICE}

This report was prepared as an account of work sponsored by the United States Government. Neither the United States nor the United States Department of Energy, nor any of their employees, nor any of their contractors, subcontractors, or their employees, makes any warranty, express or implied, or assumes any legal liability or responsibility for the accuracy, completeness or usefulness of any information, apparatus, product or process disclosed, or represents that its use would not infringe privately owned rights.

Printed in the United States of America Available from

National Technica1 Information Service U.S. Department of Commerce

5285 Port Royal Road Springfield, Virginia 22161

Price: Printed Copy $\$ 5.25$; Microfiche $\$ 3.00$ 


\section{DISCLAIMER}

This report was prepared as an account of work sponsored by an agency of the United States Government. Neither the United States Government nor any agency Thereof, nor any of their employees, makes any warranty, express or implied, or assumes any legal liability or responsibility for the accuracy, completeness, or usefulness of any information, apparatus, product, or process disclosed, or represents that its use would not infringe privately owned rights. Reference herein to any specific commercial product, process, or service by trade name, trademark, manufacturer, or otherwise does not necessarily constitute or imply its endorsement, recommendation, or favoring by the United States Government or any agency thereof. The views and opinions of authors expressed herein do not necessarily state or reflect those of the United States Government or any agency thereof. 


\section{DISCLAIMER}

Portions of this document may be illegible in electronic image products. Images are produced from the best available original document. 
GA-A15262

UC-77

\section{HTGR SPENT FUEL STORAGE STUDY}

by

R. M. BURGOYNE and N. D. HOLDER

This report was prepared as an account of work
sponsored by the United States Govermment Netther the
United States nor the United States Department of
Energy, nor any of their employets, nor any of their
contractors, subcontractors, or their employees, makes
any warranty, express or mplied, or assumes any legal
lability or responsibulty for the accuracy, completeness
or usefulness of any information, apparatus, product or
process disclosed, or represents that its use would not
infrmge privately owned nghts

Prepared under

Contract EY-76-C-03-0167

Project Agreement No. 53

for the San Francisco Operations Office

Department of Energy

GENERAL ATOMIC PROJECT 3261

DATE PUBLISHED: APRIL 1979

\section{GENERAL ATOMIC COMPANY}


•

$\checkmark$

:

: 


\begin{abstract}
This report documents a study of alternate methods of storing hightemperature gas-cooled reactor (HTGR) spent fuel.

General requirements and design considerations are defined for a storage facility integral to a fuel recycle plant. Requirements for stand-alone storage are briefly considered. Three alternate water-cooled storage conceptual designs are considered and compared to a previous aircooled design.

A concept using portable storage wells in racks appears to be the most favorable, suject to seismic analysis and economic evaluation verification.
\end{abstract}


$\bullet$ 
CONTENTS

ABSTRACT.................................... ii

1. INTRODUCTION.................................. 1

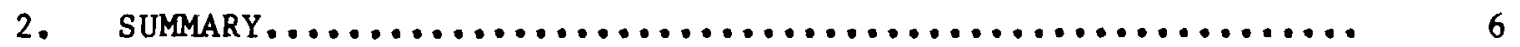

3. GENERAL REQUIREMENTS AND DESIGN CONSIDERATIONS ........... 18

3.1. General Requirements........................ 18

3.1.1. Storage Capacity..................... 18

3.1.2. Heat Removal......................... 19

3.1.3. Handling Rate....................... 20

3.1.4. Structural Arrangement................. 22

3.1.5. Maintenance......................... 23

3.1.6. Other Support Services.................. 23

3.2. Design Considerations........................ 24

4. FUNCTIONAL DESCRIPTIONS AND EQUIPMENT REQUIREMENTS......... 28

4.1. Cask Receiving............................. 28

4.2. Cask Unloading and Closure Maintenance.............. 33

4.3. Spent Fuel Storage and Retrieval................. 34

4.4. Container Emptying................................... 35

4.5. Container Refurbishment...................... 36

4.6. Container Loading......................... 37

4.7. Refabricated Fuel Storage and Retrieval............. 38

4.8. Cask Loading................................ 39

4.9. Cask Dispatching........................... 40

5. FACILITY ARRANGEMENT CONCEPTS..................... 41

5.1. Plug-Well Facility Arrangement.................. 41

5.3.1. Support Services for Integral Plant........ 48

5.3.2. Support Services for Stand-Alone Facility.... 51 
6. DEVELOPMENT REQUIREMENTS........................ 52

6.1. Structural and Seismic Analysis................. 52

6.2. Damaged Fuel Elements and Containers.............. 52

6.3. Remote Handling and Maintenance............... 52

6.4. Spent Fuel Transfer to Head End.................. 53

REFERENCES.................................... 54

\section{FIGURES}

1. HTGR shipping container with spent fuel elements.......... 2

2. HTGR fuel shipping container with recycle fuel elements..... 2

3. HTGR spent and recycle fuel rail shipping cask (SR-72)..... 3

4. HTGR spent and recycle fuel truck shipping cask............ 3

5. Material flow diagram - HRRF shipping and storage.......... 4

6. Plug-well storage concept (spent fuel)............... 12

7. Portable-well rack storage concept (spent fuel) ........... 14

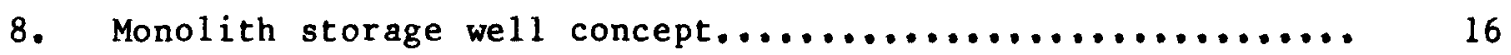

9. HRRF functional diagram showing spent and recycle fuel receipt, storage, handling, and shipping............... 29

10. Operational flow by functional area - HTGR fuel receiving, storage, and handling areas........................ 31

11. Sectional elevation of plug-well storage concept - spent fue1......................................

12. Plan of receiving, storage, and shipping facility for plugwe11 concept.................................... 44

13. Section elevation of portable-well storage concept......... 46

14. Plan of receiving, storage, and shipping facility arrangement - rack portable-well concept.......................

15. Spent fuel pool cooling and cleanup system.............. 49 


\section{TABLES}

1. General requirements for spent and refabricated fue 1

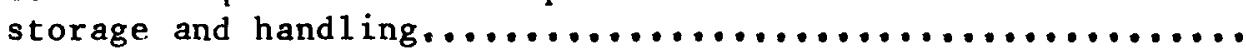

2. Design considerations for spent and refabricated fuel storage and handling requirements.................... 


\section{INTRODUCTION}

A previous study (Ref. 1) of high-temperature gas-cooled reactor (HTGR) spent fuel storage disclosed that spent fuel storage could occupy as much as $35 \%$ of the fuel recycle plant space and contribute as much as $30 \%$ of the plant capital cost. Further study of spent fuel storage therefore was begun in FY-1978, both to upgrade the design basis and to look for ways to reduce the size of the storage facility (and accompanying capital costs). The results of this study to date (December 1978) are the subject of this report. The study basis is described below and the results are summarized in Section 2 .

HTGR spent fuel is stored and handled in containers as shown in Fig. 1 (Ref. 2). After the fuel is transferred to reprocessing operations, the containers are refurbished and loaded with fabricated fuel (Fig. 2) for return to the reactor. The shipping system consists of both rail casks (Fig. 3) and truck casks (Fig. 4).

The functional flow diagram shown in Fig. 5 incorporating cask and container handling operations was used as the basis for the current study. Since cask and container handling functions must interface with refabricated fuel handling, refabricated fuel storage was included in the study.

Operations have been defined and equipment lists developed for each of the functional areas shown in Fig. 5, based on general requirements and design considerations discussed in Section 3 of this report. The 


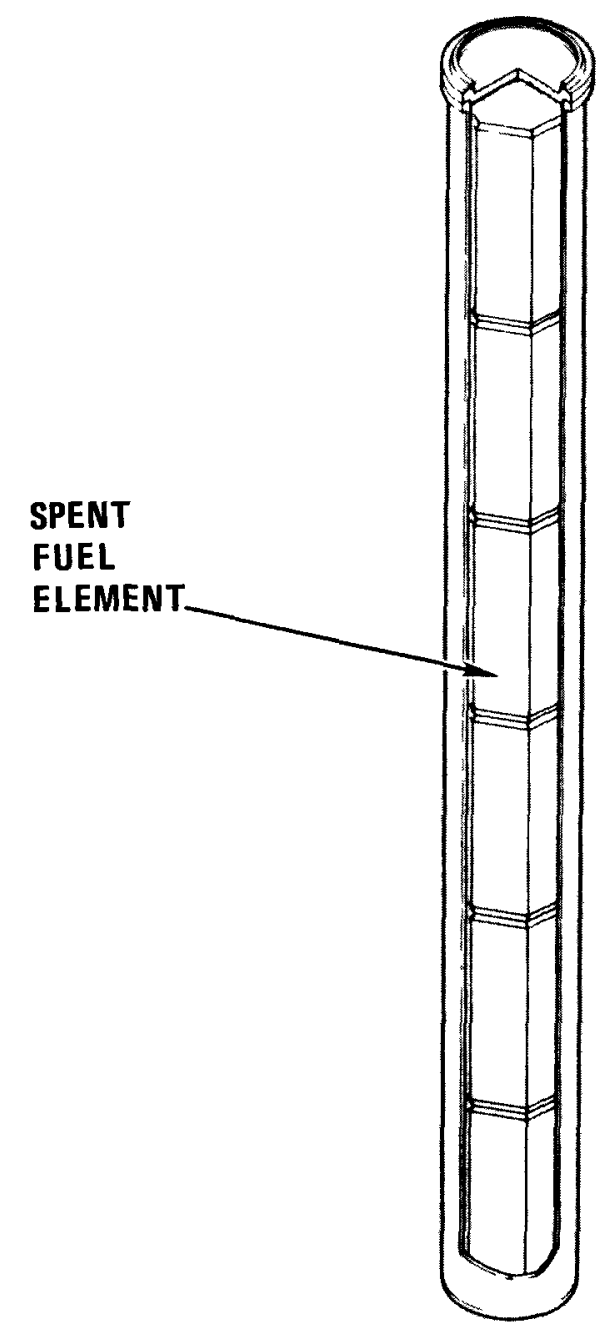

Fig. 1. HTGR shipping container with spent fuel elements

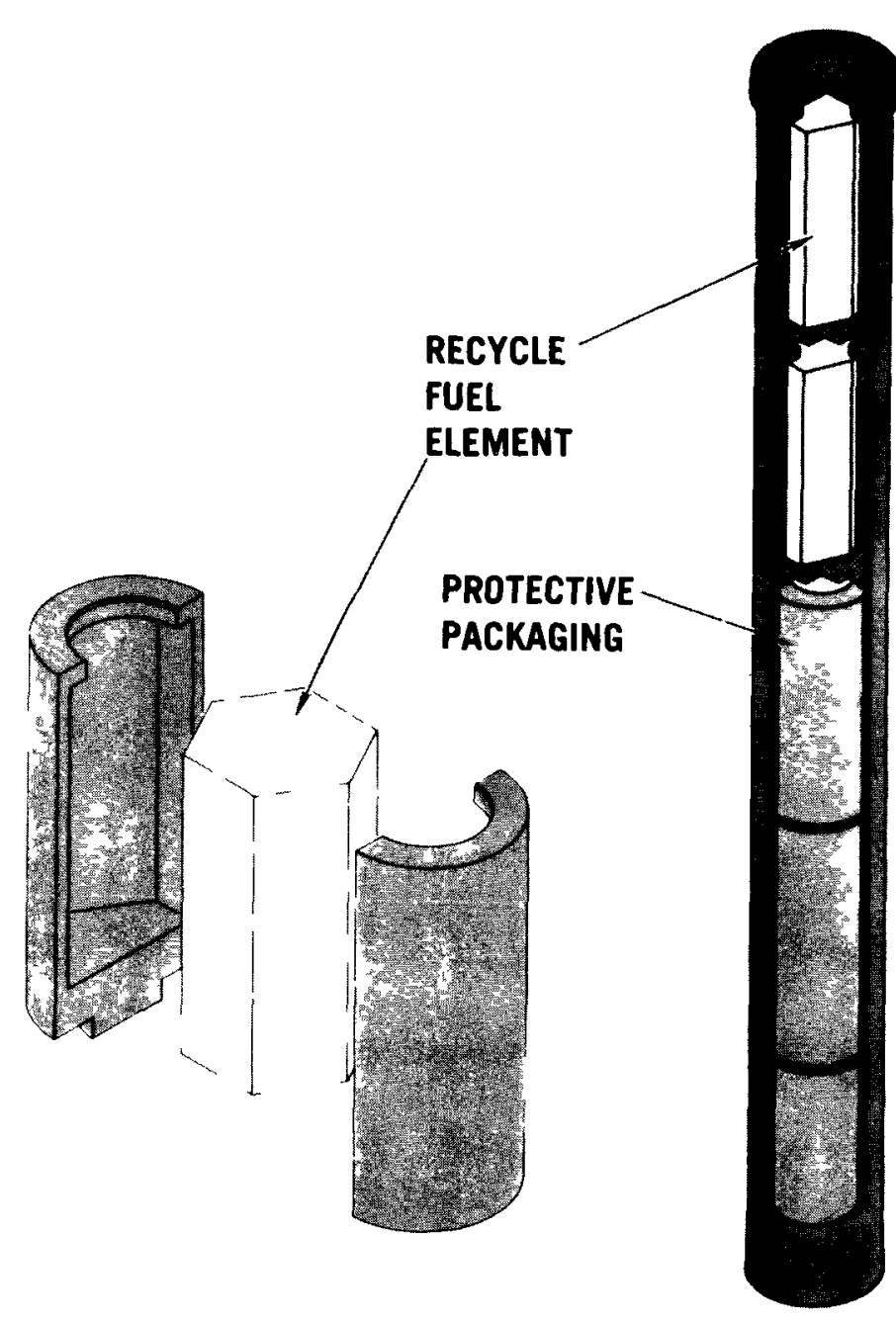
Fig. 2. HTGR fuel shipping container with recycle
fuel elements 


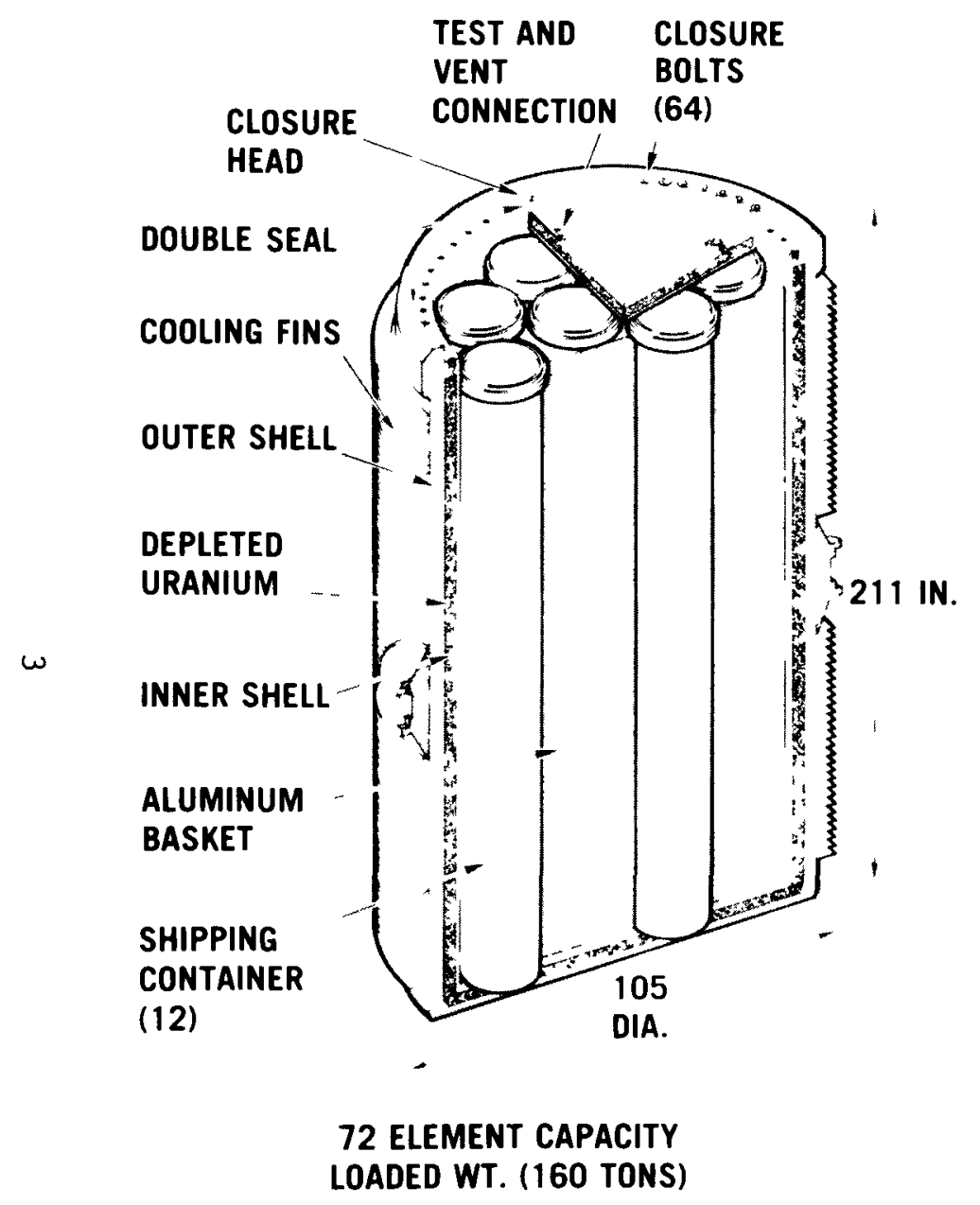

Fig. 3. HTGR spent and recycle fuel rail shipping cask (SR-72)

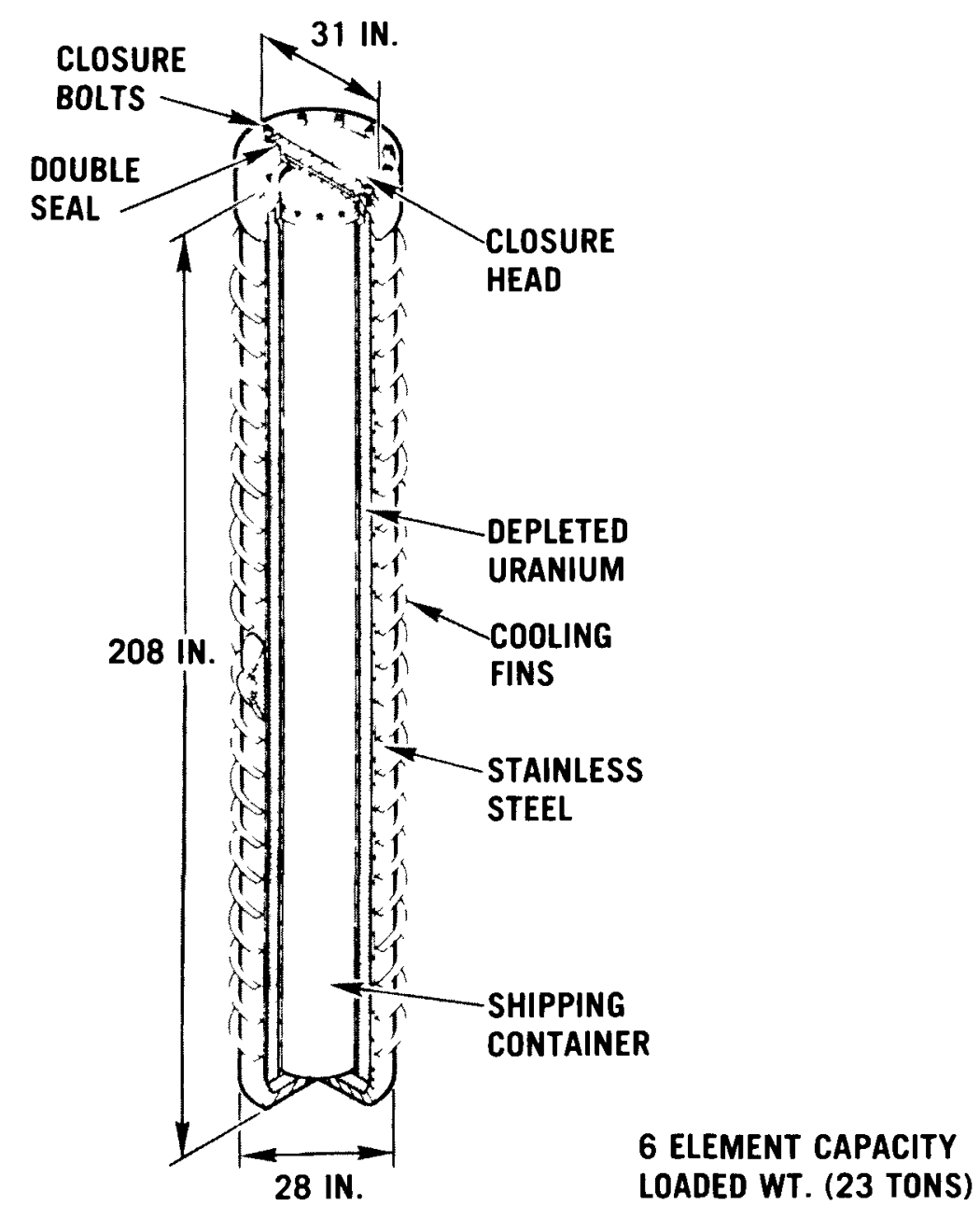

Fig. 4. HTGR spent and recycle fuel truck shipping cast (SR-6) 


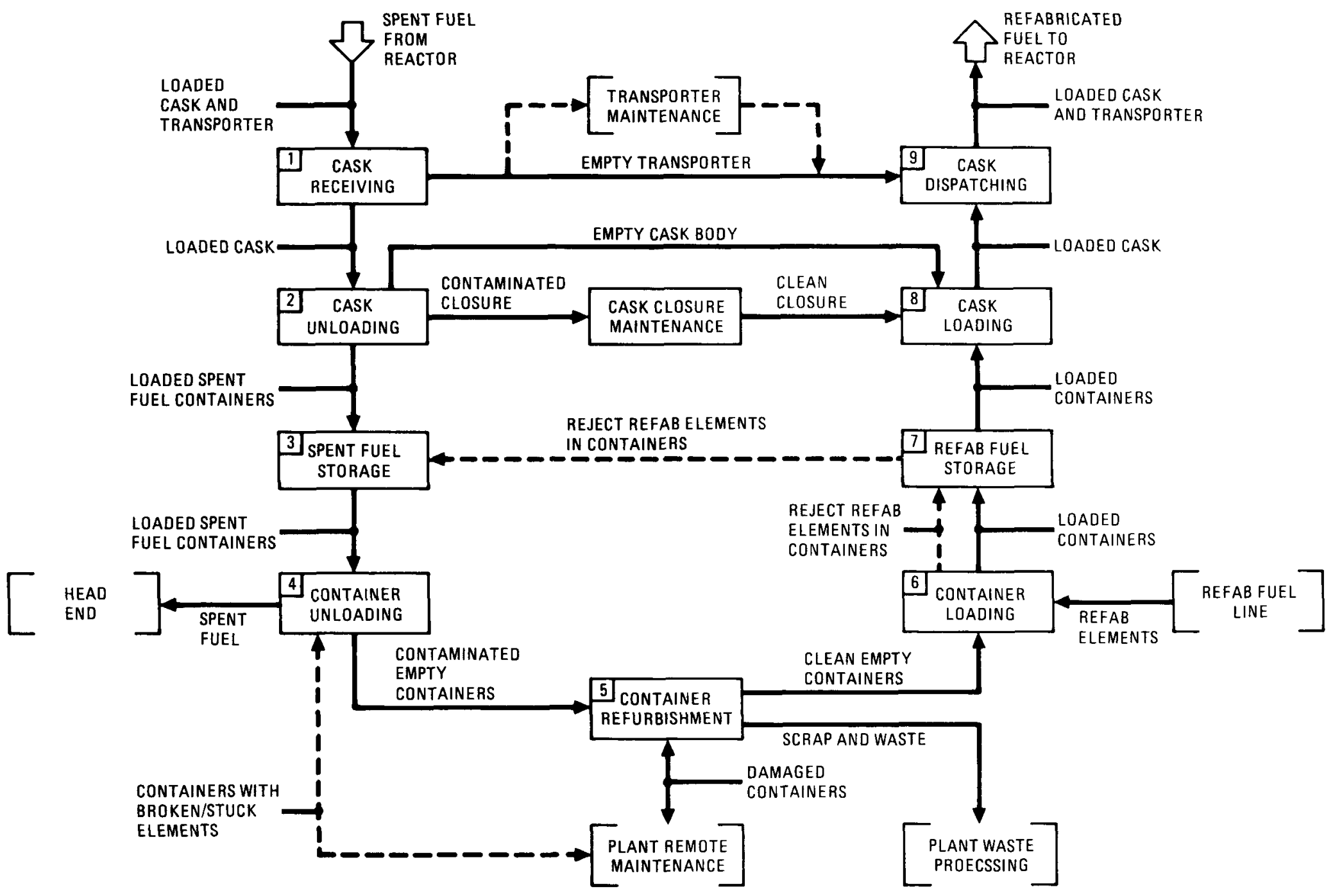

Fig. 5. Functional flow diagram - HTGR spent and recycle fuel handling and storage 
defined operations are described in Section 4. Facility arrangement conceptual designs have been developed to accommodate the operations, as discussed in Section 5. Final choice of design rests on structural and seismic considerations which were not included in the scope of this study. 


\section{SUMMARY}

This study was based on a storage facility integral to a recycle plant with capacity of 20,000 fuel elements per year. Changes necessary to convert the facility to a separate stand-alone storage facility are briefly discussed in Section 5.3.2.

Table 1 lists the general requirements developed during the study for fuel storage and handing. Rationale for the requirements is discussed in Section 3. Design considerations resulting from regulatory requirements are 1 isted in Table 2 and discussed in Section 3 along with references to more detailed requirements.

Based on the general requirements and design considerations, three spent fuel storage conceptual designs were prepared, designated as:

1. Plug-well concept.

2. Portable-well concept.

3. Monolith concept.

The plug-well concept (Fig. 6) is similar to the previous design for the target recycle plant (Ref. 1), except that water cooling is used and fuel handling has been simplified. Each storage well provides 
TABLE 1

GENERAL REQUIREMENTS FOR SPENT AND REFABRICATED FUEL

STORAGE AND HANDLING

Storage Capacity

1. Spent fuel storage equivalent to 90 days reprocessing capacity (minimum).

2. Refabricated fuel storage equivalent to 90 days refabrication capacity (minimum).

3. Storage for rejected refabricated fuel elements equivalent to $1.5 \%$ of the annual refabrication throughput.

Heat Removal

1. Provision for receipt of fuel 100 days after reactor discharge.

2. Water cooling for spent fuel.

3. Natural convection air cooling for refabricated fuel. 
TABLE 1 (Continued)

Hand 1 ing Rate

1. Two rail casks turned around in 24 hours.

2. Two truck casks turned around in 12 hours.

3. Provision of spare loading ports and equipment for maximum availability.

4. Storage area - two containers/hour/system.

5. Container opening - one container/hour.

6. Container loading - one container/hour.

7. Container refurbishment - one container/hour.

8. Automatic indexing to storage well.

\section{Structural Arrangement}

1. Physical separation of spent and refabricated fuel operations.

2. No segregation of U-233 and U-235 fuel containers (must be identifiable, however). 


\section{TABLE 1 (Continued)}

\section{Structural Arrangement}

3. No special handling of leaking containers.

4. Double containment of fuel where water cooling is used.

5. Storage area based on two fuel containers per storage well (subject to seismic analysis verification).

6. Crane handling of shipping casks.

Maintenance

1. Transporter maintenance to be performed in separate facility.

2. Container and cask closure refurbishment done in storage facility (seals replaced manually).

3. Other major maintenance done in recycle plant maintenance cells.

\section{Other Support Services}

1. Separate off-gas treatment for storage areas.

2. Water cleanup/cooling for spent fuel storage pool.

3. Other major utilities and services provided by recycle plant. 
TABLE 2

DESIGN CONSIDERATIONS FOR SPENT AND REFABRICATED

FUEL STORAGE AND HANDLING REQUIREMENTS

Structural Integrity

1. Integrity of the fuel elements must be maintained.

2. The pool structure must provide for minimum leakage.

3. The pool should be below grade and have a high degree of resistance to ground motion.

4. The pool should withstand the stress of water boiling.

5. The storage racks and wells should be structurally compatible with seismic and missile protection design criteria.

Radioactivity Levels

1. There should be provision for isolating sections of the pool when necessary.

2. Personnel exposure should be limited in accordance with 10CFR20 during cask handling. 


\section{TABLE 2 (Continued)}

3. The ventilation system should keep activity levels in occupied areas as low as practicable and within the limits of 10CFR20.

4. Liquid effluents must be treated to ensure that radioactivity is as low as practicable and within the limits of 10CFR20.

\section{Accident Conditions}

The design should preclude credible accidents.

\section{Accountability}

Special nuclear material must be accounted for and physically protected.

Criticality

The design should allow an acceptable margin of nuclear criticality safety in all normal and accident handling modes. 


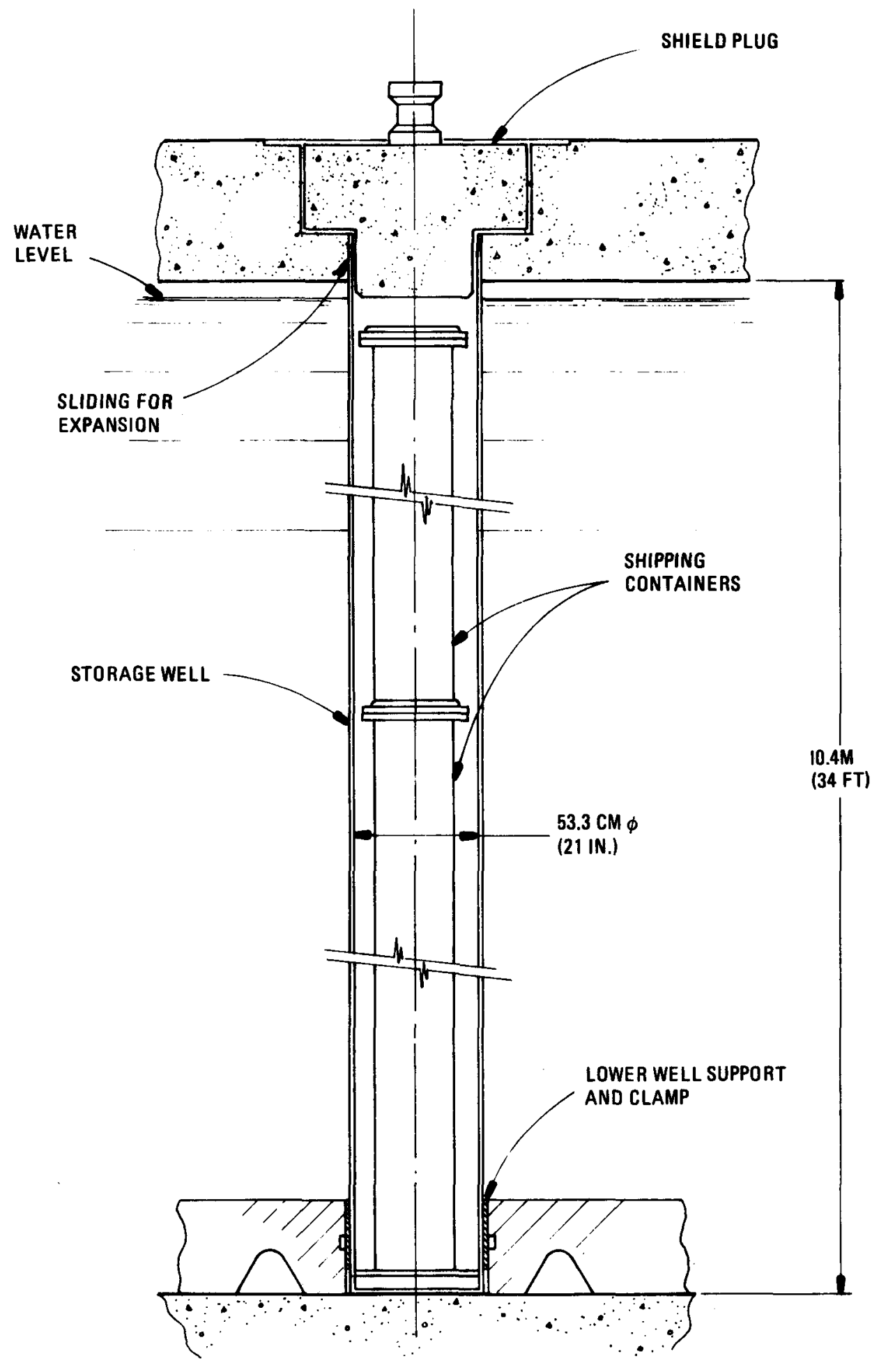

F1g. 6. Plug-well storage concept (spent fuel) 
containment and isolation of two fuel containers from the water cooling medium, where the previous design handled only one container per well. Fuel handling operations are fully remote, and personnel access to the area over the storage pool is not permitted. Cleanup of air above the storage wells, in the fuel handling cell, and in the cask unloading area requires off-gas treatment. A stainless steel pool 1 iner and a heavy shielding floor to support the wells are needed. The storage wells are remotely replaceable should this be required for any reason.

A preliminary facility layout and description are given in Section 5. Seismic and structural analysis is required to determine the supporting members needed for the shielding floor and to evaluate the possible seismic effects of two-container wells. Since the two-container wells provide the major space reduction $(\sim 25 \%)$ and potential cost saving over the target recycle plant design, it is important to determine the feasibility of stacking two containers per well before choosing a final design.

The portable-we11 concept (Fig. 7) utilizes rack storage similar to light water reactor pools. This concept reduces the volume of air requiring cleanup, and permits personnel access and use of the area directly over the storage wells. Double containment (isolation of the fuel containers from the cooling water) is provided, as for the plug-well concept; however, the two-container wells are carried to an overhead port for loading and are returned to the rack when filled. The floor over the pool can be 1 ighter than for the plug-well arrangement since it does not bear the weight of the wells. Both the racks and wells can be replaced if required.

A preliminary facility layout and description are given in Section 5. Seismic and structural analysis is required to determine supporting 


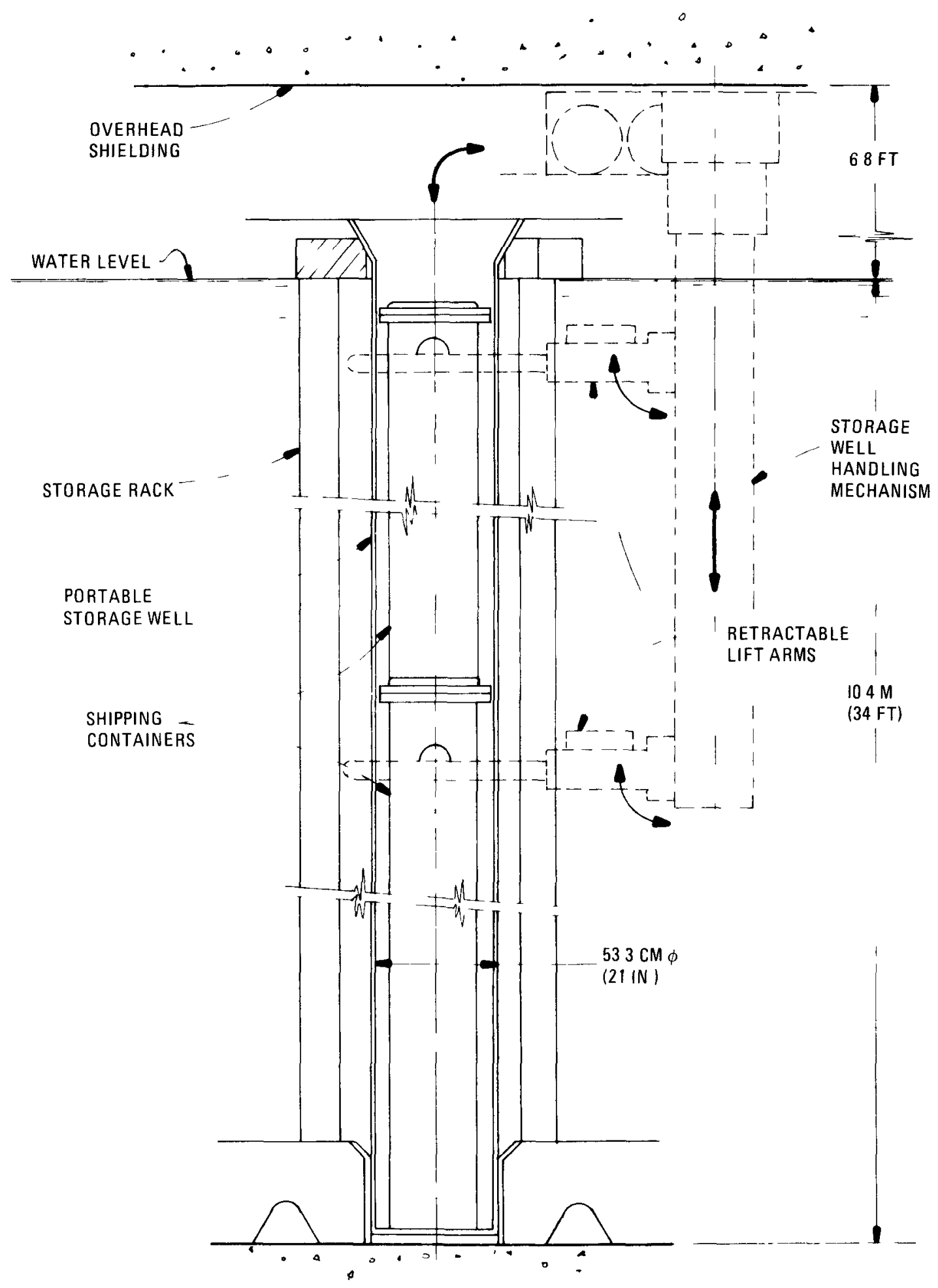

Fig. 7. Portable-wel1 rack storage concept (spent fue1) 
members needed for the floor and to evaluate seismic effects on the racks and the two-container wells.

Since the two containers per well and the portable wells in racks provide the major space reduction $(260 \%)$ and potential cost saving over the target recycle plant design, it is important to determine the feasibility of stacking the containers in the well and storing the containers in racks before choosing a final design.

The monolith concept, shown in Fig. 8, was briefly examined as an alternative. Previous studies for HTGR reactor spent fuel storage (Ref. 4) have indicated that the monolith concept is both difficult to build and expensive. This concept was therefore not carried forward to a facility layout; it is mentioned as a possibility should the other designs not prove seismically feasible.

In addition to savings in space and capital cost, water-cooled storage offers the following advantages:

1. The volume of air requiring of $\mathrm{f}-\mathrm{gas}$ cleanup is reduced.

2. Water pool and cleanup system technology is we11-developed.

3. Greater safety is provided under $108 s$ of cooling medium circulation.

The ranked order of preference for the designs is:

1. Portable-well water-cooled concept.

2. Plug-we11 water-cooled concept. 


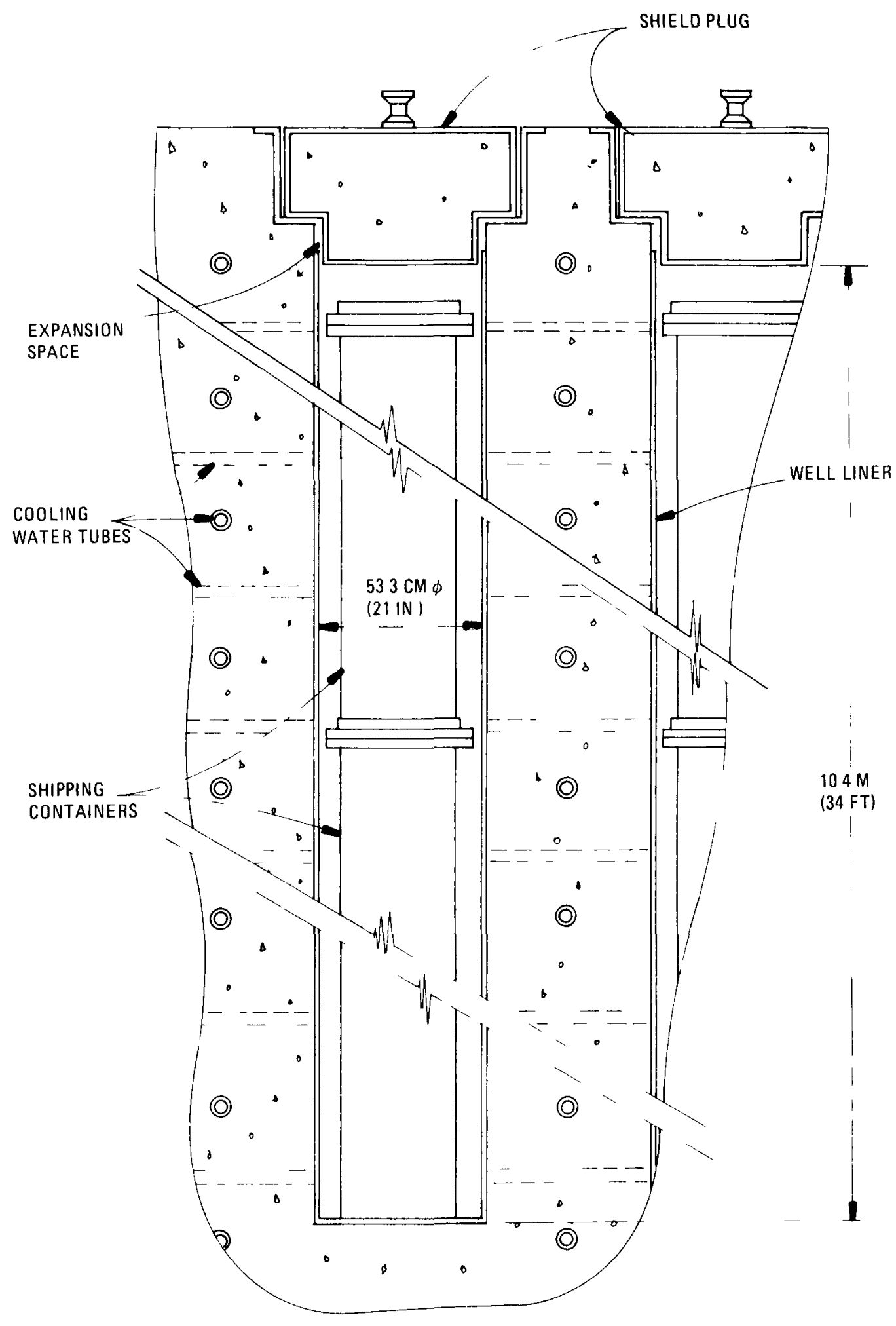

Fig. 8. Monolith storage well concept 
3. Target recycle plant air-cooled concept.

4. Monolith water-cooled concept.

The next step should include seismic and structural analysis of the portable-well and plugged-well concepts. The layouts should be revised as necessary to reflect the results of the analysis, and cost estimates should be performed to determine the most economical storage design. 


\section{GENERAL REQUIREMENTS AND DESIGN CONSIDERATIONS}

General requirements are included for such items as capacity, hand1 ing rates, arrangement, and support services. Design considerations arise from regulatory requirements and guidelines. This study has considered only major items in each category as discussed below.

\subsection{GENERAL REQUIREMENTS}

General requirements are based on a set of arbitrary definitions that must be available before a design can be developed. In most instances, other sets of definitions would do as wel1; the chosen set merely establishes a baseline for evaluating alternative design concepts. The chosen requirements are summarized in Table 1 (Section 2) and discussed in detail below.

\subsubsection{Storage Capacity}

The size of the storage facility depends upon several variables including the number of reactors served, the timing of reactor startup and fuel discharge, the size of reactors served, the reference fuel cycle, other available storage, and the reprocessing (throughput) or disposal philosophy. Since no specific criteria for determining ranges of values for these variables currently exist, this study is based on the following: 
1. Storage facility integral with a spent fuel reprocessing and a fuel refabrication facility.

2. Design capacity for reprocessing of 20,000 fuel elements per year (Ref. 4).

3. One refabricated fuel element produced for each two spent fuel elements processed.

4. Rejected (scrap) refabricated fuel elements accumulated for one year in storage prior to reprocessing at an assumed $1 \%$ scrap rate (50\% excess storage provided).

5. Ninety days surge storage provided for reprocessing head-end operations and for refabricated fuel product.

\subsubsection{Heat Removal}

HTGR fuel cycle economics are based on a 1-year turnaround time for converting spent fuel to refabricated fuel. That is, uranium discharged will be received back at the utility as refabricated fuel for the next reactor reload. The spent fuel shipping system is designed to handle 100-day-cooled fuel to achieve this turnaround; the storage facility must then be able to receive approximately 100-day-old fuel.

Based on the 100-day-cooling assumption, it is felt that forced circulation water cooling should be employed for spent fuel storage. It was judged that the high heat load, combined with the desirability of closely spaced wells to minimize the storage area size, could be handled by the higher-efficiency water cooling system. It was further believed desirable to minimize the volume of air requiring cleanup to meet 
overall plant site air quality standards. Since water pools and cleanup systems are employed exclusively throughout the LWR fuel cycles, this technology is well known. Additionally, it was felt that a water cooling system provided greater safety should a loss of circulation occur. With air cooling systems, extensive backup systems would be required to ensure adequate air circulation at all times. For water cooling, however, backup systems can be minimized since the pool provides an adequate heat sink, even if allowed to boil. Emergency makeup water can readily be supplied and a considerable response time is available to effect corrective action before any serious fuel heatup problem would be encountered.

The refabricated fuel heat load and activity level is low, and natural convection air cooling is considered adequate.

\subsubsection{Handling Rate}

Previous studies (Ref. 5) have indicated that the most economical mix of rail and truck shipping for HTGR fuel is $90 \%$ by rail and $10 \%$ by truck. Based on this mix, approximately 250 72-element rail and 333 6element truck casks will be handled annually at the storage facility.

To maximize both utility customer service and cask usage, sufficient loading ports and handling equipment are provided so that the storage facility can receive or ship fuel 365 days per year. The average receiving rate is therefore approximately five rail and $s$ ix truck casks per week. Utilities will normally want to refuel when power demand is low. Since power demand tends to follow seasonal changes, spent fuel discharge peaks in the spring and fall of the year. Although spent fuel storage time at the reactors can be extended beyond 100 days, studies have shown (Ref. 6) that this results in a reactor fuel turnaround time greater than one year. The longer turnaround time is undesirable 
because it results in fuel cycle cost penalties. Therefore, for this study, it is assumed that additional casks are available to accommodate peak shipping loads. The maximum receiving rate is assumed to be doubled for rail casks and quadrupled for truck casks to allow for the seasonal peak.

For efficient cask utilization, turnaround time must be minimized. Time and motion studies have shown (Ref. 7) that rail casks can probably be turned around in less than 24 hours and truck casks in less than 12 hours. The net result is a handling rate requirement of (1) two rail casks in 24 hours; and (2) two truck casks in 12 hours.

Rail casks contain 72 fuel elements in 12 containers; truck casks contain 6 fuel elements in 1 container. The maximum cask receipt rate results in 28 spent fuel containers handled per 24 hours in the storage area. At the same time, other containers must be removed from storage for transfer to head-end reprocessing at a rate of about 14 containers per 24 hours as described below. The result is that the storage area systems must handle 42 containers in 24 hours or approximately two containers per hour. The handling rate from the rail cask to the interim storage area must consider that part of the cask turnaround time is used up in cask handling. The transfer rate is three containers per hour per rail cask. Truck cask unloading requires handling only one container per hour.

The reprocessing head end system handles 20,000 fuel elements in an equivalent 233 days, or 86 fuel elements per day maximum. At 6 elements per container, 14 containers must be handled per 24 hours. Since the fuel element crushing system can handle four or more fuel elements per hour and has surge storage to provide a backlog against failures, a handling rate of one container per hour has been specified for the loading and unloading and refurbishment stations. 
Since the fuel must be processed according to customer batch for accountability purposes, and since searching for containers would be time consuming under remote handling conditions, a computerized data storage and retrieval system and automatic indexing of handling equipment will be provided.

\subsubsection{Structural Arrangement}

To preclude the mixing of spent and refabricated fuel elements, their handling and storage areas must be physically separated. Within the refabricated fuel storage area there is no requirement to separate fuel elements refabricated using $U-233$ from those refabricated using U-235, although containers and contents must be identifiable.

Storage wells for containers are provided so that the fuel is doubly contained. Leaking spent fuel containers are not specially handled since both off-gas and water cleanup are provided. Facility arrangement is based on two containers per storage well pending verification of seismic feasibility.

Facility arrangement allows for cask removal from transporters by crane to avoid providing specially designed cask uprighting and handing mechanisms, to simplify track routing, and to allow maintenance operations on the transporter to be done in parallel with the unloading operations. 


\subsubsection{Maintenance}

Since the storage facility is an integral part of the recycle plant, many maintenance functions can be performed in recycle plant facilities. Container and cask closure minor repair and seal replacement functions are included in the storage facility to expedite cask turnaround. The transporter (rail car or truck and trailer) are sent to nonradioactive shop facilities for maintenance while the containers are being unloaded from the cask. Maintenance of storage facility equipment is done in recycle plant maintenance cells. Any fuel that cannot be removed from a container is recovered in the recycle maintenance cells. Any containers that require major rework or that must be discarded are handled in the recycle maintenance cells.

\subsubsection{Other Support Services}

Services required other than maintenance include the following:

off-gas treatment.

Water treatment.

Liquid waste disposal.

Solid waste disposal.

Chemical makeup and storage.

Laundry, change rooms, and cafeteria.

Emergency utilities.

Sewage treatment.

Water supply.

Power supply.

Heating, ventilating, and air conditioning.

Spare equipment and parts storage.

Administration.

Rail access (including yard locomotive). 
Analytical laboratory services.

Fire protection.

Security services.

Health physics and medical services.

Only off-gas treatment and water treatment are considered to be dedicated systems for sole use of the storage facility. The balance of the services are assumed to be furnished by the recycle plant. This assumption is not compatible with operating the storage facility several years in advance of the recycle plant.

\subsection{DESIGN CONSIDERATIONS}

In addition to considerations resulting from the general requirements above, the facility design should incorporate regulatory requirements and guidelines, such as:

Regulatory Guide 3.24 - Guidance on the License Application, Siting, Design and Plant Protection for an Independent Spent Fuel Storage Installation

Regulatory Guide 1.27 - Ultimate Heat Sink for Nuclear Power Plants

10CFR Part 20 - Standards for Protection Against Radiation

Safeguards considerations must be addressed in the design. Special nuclear material accountability requirements have been considered in this study but physical protection requirements, such as set forth in Regulatory Guides 5.7, 5.12, 5.20, and 5.30 and in 10CFR50 Appendix $Q$ and 10CFR73, were not considered since they will be addressed in the overall recycle facility design. In this study, special nuclear material accountability has been considered both for safeguards as 
required in 10CFR70 and 10CFR50 and for customers. Fuel elements and containers are serially numbered for identification and provide an item count basis for accountability. Weight and gross gamma monitoring is used to verify contents of sealed containers. Al1 information on container location and content is computer-monitored to facilitate retrieval and inventory.

Later structural and seismic studies should consider structural guidelines given in ANSI Standard N305, "Design Objectives for Highly Radioactive Solid Material Handling and Storage Facilities in a Reprocessing Plant." The "Fuel and Waste Storage Facilities" section of ANSI Standard N101.3, "Guide to Principal Design Criteria for Nuclear Fuel Reprocessing Facilities," should also be considered.

Design considerations based on the above regulations and guidelines include the following (regulations should be consulted for information on which items are mandatory and which are recommended):

1. Integrity of the primary barrier to the release of radioactive materials must be maintained.

2. The storage pool should be built below grade and be designed with a high degree of resistance to ground motion.

3. The pool should be built in impervious soil or with a secondary water containment envelope.

4. There should be provision for isolating sections of the pool when necessary, or the pool should be built as a series of separable modular units. 
5. Means should be provided for limiting the exposure of personnel in accordance with 10CFR20 during cask handling.

6. The ventilation system should keep the activity levels in occupied areas as low as practicable and within the 1 imits of 10CFR20.

7. Radioactive liquid effluents must not be discharged to the natural area drainage system, or they must be treated to ensure that radioactivity is as low as practicable and within the limits of 10CFR20.

8. Contaminated wastes should be rendered into a form suitable for land burial or shipment to a federal repository.

9. The design should preclude the following as credible accidents:

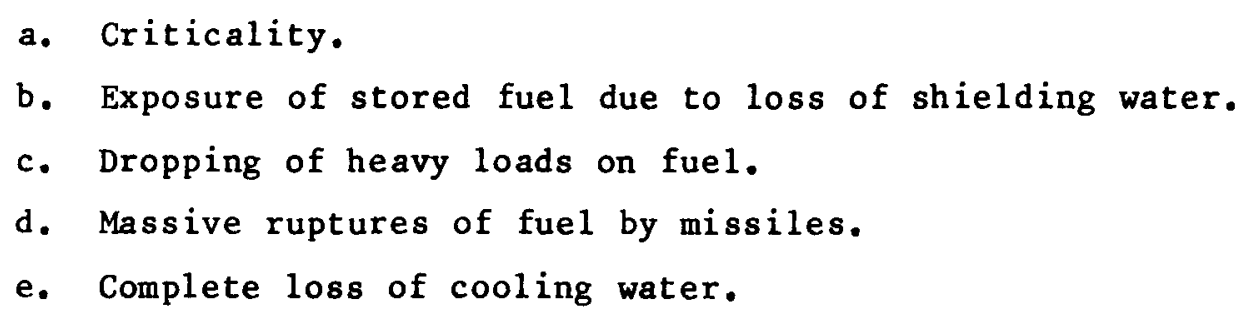

10. Storage racks (and wells) should be spaced to meet criticality requirements and be structurally compatible with seismic and missile protection design criteria. Safe spacing should be maintained under abnormal conditions. 
11. Cask handing cranes should not pass over the fuel storage pool.

12. The building need not be designed to withstand high winds, provided critical equipment is protected.

13. The pool structure should withstand the stress of water boiling, and an assured source of makeup water should be provided. Otherwise, the heat removal systems must be protected from credible accidents and have a backup power supply.

14. A stainless steel or other suitable liner should be used to meet minimum leakage requirements.

15. The storage and handling equipment and pool liner should be resistant to corrosion by the coolant.

Other potential detailed guidelines and references to miscellaneous regulatory requirements $c$ an be found in ANSI.N.210, "Design Objectives for Light Water Reactor Spent Fuel Storage Facilities at Nuclear Power Stations."

Based on the general requirements and design requirements, functional descriptions and equipment requirements have been developed as discussed in the following section. 


\section{FUNCTIONAL DESCRIPTIONS AND EQUIPMENT REQUIREMENTS}

The flow diagram shown in Fig. 9 depicts overall operational interactions within the receiving, storage, and handing facilities. Included are all operational elements necessary to receive, handle, store, retrieve, and feed spent fuel to the reprocessing head end and to acquire, load, store, retrieve, and ship the recycle fuel from the refabrication line. Also included are support operations associateed with maintenance and servicing of the shipping cask and containers.

The storage facility has been divided into nine functional areas incorporating the above operations. The functions are correlated but require discrete operational, facility, and equipment considerations. These functional relationships are summarized in Fig. 5, Section 1, and are shown in more detail in Fig. 10. The nine functional areas shown are generic to the facility regardless of the storage scheme adopted.

\subsection{CASK RECEIVING}

The primary function of this area is to reconfigure the shipping cask for insertion into the cask unloading port. The shipping cask arrives at the recycle plant on either a truck or rail transporter. Based on the assumed split of $90 \%$ rail and $10 \%$ truck shipping, approximately 250 rail and 333 truck casks are handled annually. Through redundancy of equipment, $100 \%$ availability for the storage facility is assumed; therefore, the annual receiving rate is approximately five rail and six truck casks per week. This volume could be handled easily with 


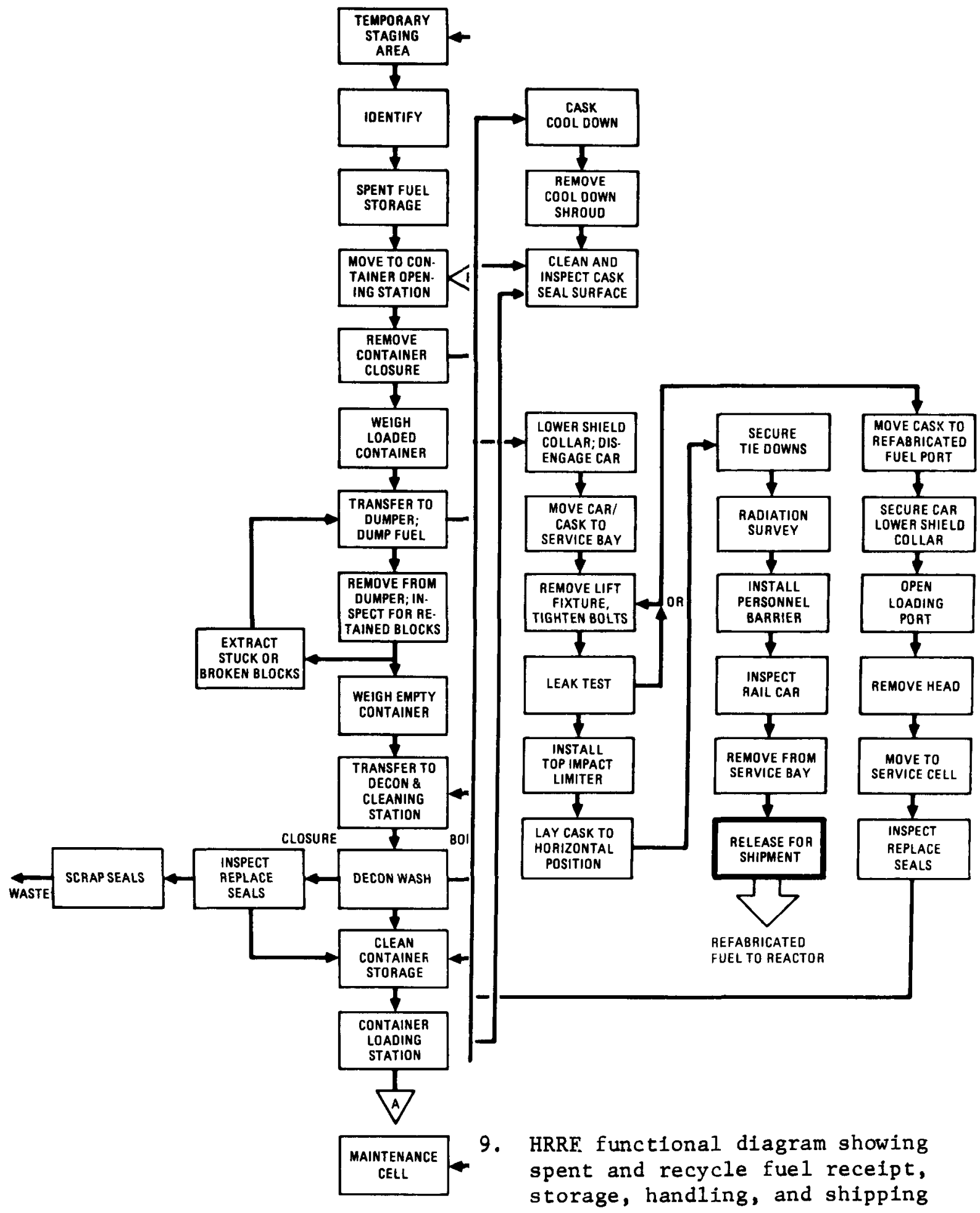


-

:

: 


\begin{tabular}{l}
\multicolumn{1}{|c|}{1 CASK RECEIVING } \\
PERFORM RECEIPT INSPECTION \\
PERFRM CASK WASHDOWN \\
REMOVE PERSONNEL BARRIER \\
DISENGAGE TEDOWN \\
REMOVAL FROM TRANSORTER ERECT \\
MOUNT ON TRANSER CAR \\
REMOVE TOP IMPACT LIMITER \\
CLEAN CAS TOP AND HEAD \\
MONITOR RADIATION \\
SAMPLE AND PURGE CAVIY \\
INTALL CLOSURE LFTING GEAR \\
REMOVE CLOSURE BOLTS \\
MOVE CASK TO SPENT FUEL PORT \\
\end{tabular}

\begin{tabular}{|c|}
\hline 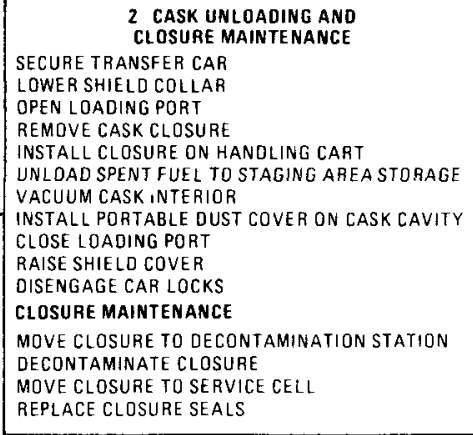 \\
\hline
\end{tabular}

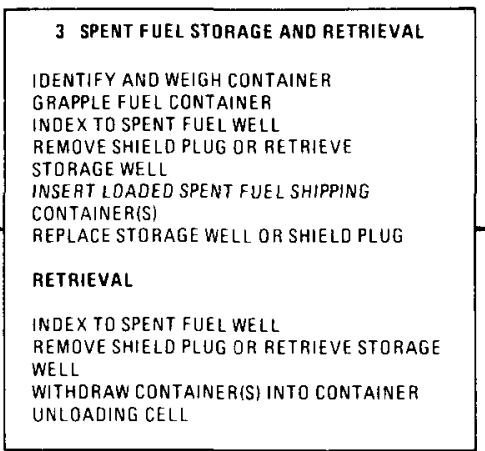

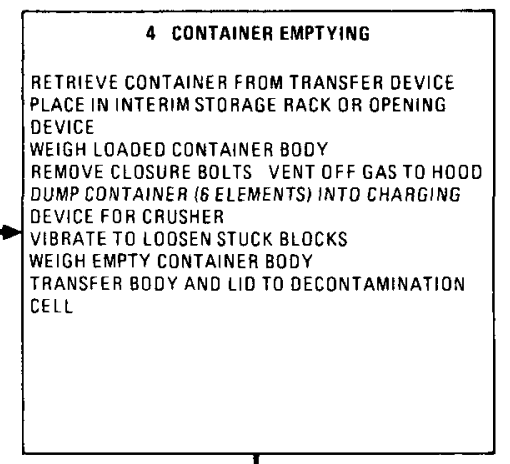

\section{CONTAINER REFURBISHMENT} RECEIVE EMPTY CONTAINER COMPONENTS SPRAY DECONTAMINATE AND RINSE TRANSFER LID TO SERVICE CELL CHARGE CLOSURE SEALS INSPECT/REPLACE BOLTS PLACE LIOS IN CLEAN STORAGE INSPECT CONTAINER BODY SEAL SURFACE
PLACE BODY IN CLEAN STORAGE TRANSFER DEFECTIVE PARTS TO MAINTENANCE CELL

\section{CONTAINER LOADING}

RECEIVE EMPTY CONTAINER BODY MOUNT IN LOADING STATION RECEIVE REFAB FUEL IDENTIFY OAD IN CONTAINER IS ELEMENTS: ASSEMELE ON CONTAINER TOROUE BOLTS LEAK TEST CONTAINER SEALS IDENTIFY AND WEIGH CONTAINER
TRANSFER LDADED CONTAINER TO STORAGE EXCESS CONTAINERS REPLACE CONTAINER LID
MOVE TO EMPTY CONTAINER STORAGE MOVE TO EMPTY LOADING

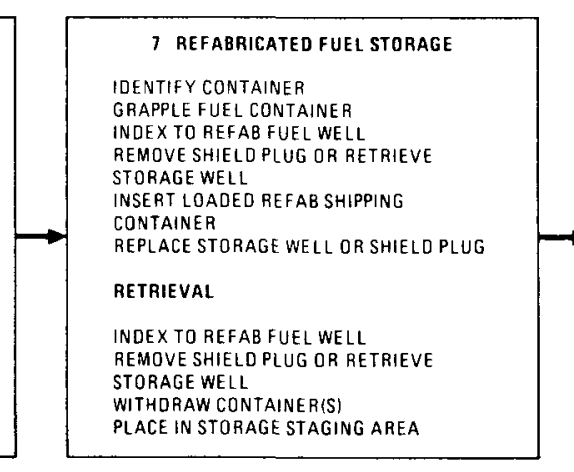

7 REFABRICATED FUEL STORAGE IDENTIFY CONTAINER SHIELD PLUG OR RETRIEV INSERT LOAOLO REFAB SHIPPING REPLACE STORAGE WELL OR SHIELO PLUG

\begin{tabular}{l} 
B CASK LOADING \\
MOVE CASK FROM SPENT FUEL LOADING PORT \\
SECURE TRASFER CAR \\
LOWER SHIELO COLLAR \\
OPEN LOADING PORT \\
ATTACH CASK COOL DOWN DEVICE \\
COOL DOWN CASK (FOR REFAB RELOAD ONLY) \\
REMOVE DUST COVER \\
LOAD REFAB FUELLEMPTY CONTAINERS \\
REINSTALL CASK CLOSURE \\
CLOSE LOADNG PORT \\
RAISE SHIELO COLLAR \\
DISENGAGE CAR LOCKS \\
DEONTAMINATE CASK \\
MOVE CASK TO SEAVICE BAY FOR \\
DISPATCHING \\
\hline
\end{tabular}
1

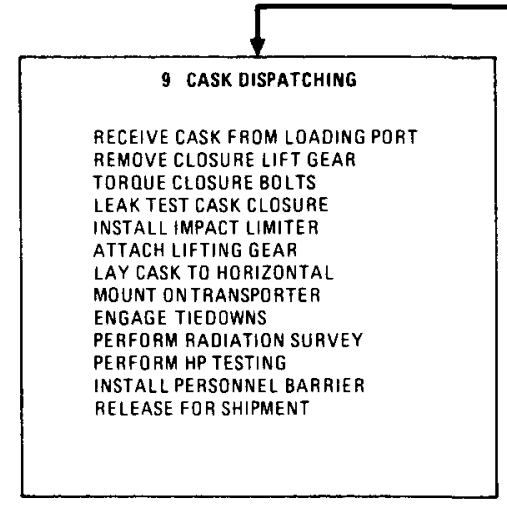

Fig. 10. Operational flow by functional area - HTGR fuel receiving, storage, and handling areas 
single loading ports, based on the turnarounds assumed. However, studies have indicated that reactor discharges tend to follow seasonal peaks, with most discharges likely to occur in the spring and fall. This essentially doubles the shipping rate during peak seasons and requires additional cask loading ports. Since the rail casks represent $90 \%$ of the traffic, three ports are specified for them, while two are specified for truck casks to provide redundancy and meet availability objectives. The cask receiving area therefore has capabilities to service all five loading ports.

After arrival on site, a preliminary receipt inspection is performed to verify that the cask is undamaged and to identify the reactor customer. Health physics checks are performed, and maintenance for the transporter is scheduled in accordance with the maintenance plan. Routine maintenance is performed in parallel with the other cask handling operations using recycle plant facilities.

After receipt inspection, the cask is routed to the service bay. The rail cars and trailers are moved with special transfer engines. The normal locomotive or tractor can be released or secured to a departing cask. At the service bay, the personnel barrier is removed and tiedowns are disengaged. The cask is lifted from the transporter by a 160-ton bridge crane and the cask is placed in an upright position on a transfer dolly. The transfer dolly moves the cask on transfer car rails underneath the unloading port (see facility layout description in Section 5.1, for example). Before the cask is positioned underneath the port, the impact limiter and closure bolts are removed. The head is cleaned and monitored. The cask cavity is sampled and if the activity level is high the cavity is purged to the offgas system prior to removal of the closure bolts. Closure lifting gear is installed before mating with the port. 
Equipment Requirements:

Rail car transfer engine.

160-ton-capacity crane, 30-ton hook.

5-ton-capacity crane.

Transfer car, 160-ton capacity.

Transfer car, 30-ton capacity.

Cleaning equipment, steam and hot water.

of $f-g$ as hand 1 ing.

Closure bolt pneumatic torquing equipment.

Work plat forms.

Turntables.

4.2. CASK UNLOADING AND CLOSURE MAINTENANCE

The transfer car is secured under the loading port, a shielding collar is lowered around the cask head, and the loading port is opened. The cask closure is removed and installed on a handing cart for transfer to maintenance.

The spent fuel containers are removed from the cask to temporary holding wells in the unloading area. The cask interior is vacuumed, the temperature monitored, and a portable dust cover is installed. The cask is disengaged from the unloading port and moved to an adjacent refabricated fuel loading port.

The cask closure is decontaminated and moved to a service cell for inspection and seal replacement as necessary. The closure is then moved to the refabricated fuel loading area. 
Equipment Requirements:

Cask loading port with shield cover.

Shielding collar.

Transfer car locks.

Cask closure handling cart.

closure head decontamination equipment.

5-ton-capacity crane.

2-ton-capacity PAR* manipulator and grapple.

Seal service equipment.

Cask portable dust cover.

Remote TV.

\subsection{SPENT FUEL STORAGE AND RETRIEVAL}

At the temporary holding wells in the unloading area, the container serial number is read and the container is weighed. The data are compared with the shipping bill of lading for shipper/receiver material balance closure and entered into the computerized storage information system as the beginning storage inventory. The spent fuel storage container is moved by an indexing handling mechanism to a storage we 11 in the spent fuel storage area. In the portable-well concept, the well is removed from its rack and brought to the temporary holding area, receives two containers, and is indexed back to its rack position.

For spent fuel retrieval, containers for the customer batch to be processed are located by the indexing system and transferred as needed to a rotating device that allows transfer to the container opening cell

*Programmed and Remote Systems Corp., St. Paul, Minnesota. An equivalent device may be substituted. 
(see Section 5.1). In the portable-well concept, the storage well is removed from its rack and moved to a position below the containeremptying cell for container removal.

Equipment Requirements :

Storage wells and plugs.

Two 5-ton-capacity bridge-mounted PAR manipulators with plug handling device and container grapple (plug-well storage).

Container-weighing device on PAR manipulator.

Computer-controlled index device on fuel handing mechanism.

Remote TV.

Two 5-ton-capacity storage-wel1 transporters (portable-wel1 storage).

Container transfer mechanism (1azy Susan) for transfer of container from storage to the container opening cell (plug-well storage).

Storage racks (portable-well storage).

\subsection{CONTAINER EMPTYING}

The container is retrieved from the container transfer device or portable storage well and moved to an interim storage rack or directly to the container opening station. The container is identified and weighed for storage material balance closure. The closure bolts are removed and the off-gas is vented to a hood for transfer to the treatment system. The container contents are transferred to the fuel element crusher charging device. The empty container is weighed to verify that all material has been removed and to provide net weight information for the reprocessing plant beginning material balance. If any material remains in the container, it is vibrated in an attempt to remove it. If material cannot be removed, the container is transferred to the reprocessing hot maintenance cell for retrieval of the fuel material. 
If the container has been successfully emptied in the container-emptying cell, both body and 1 id are transferred to the adjacent decontamination ce11.

Equipment Requirements:

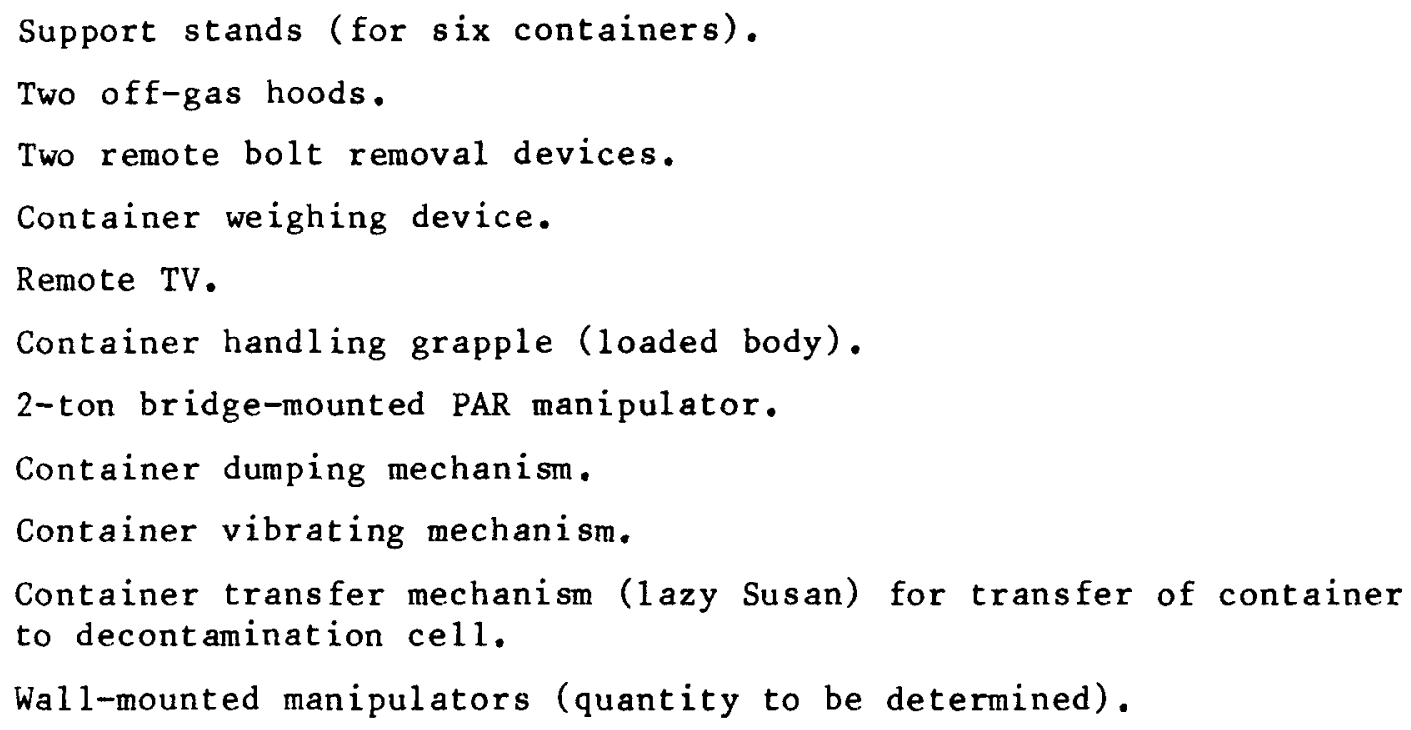

\subsection{CONTAINER REFURBISHMENT}

Empty containers and 1 ids are received from the container emptying cell and occasionally from the reprocessing maintenance cell after stuck block removal. The containers and lids are spray washed for decontamination, rinsed, and dried. The lids are transferred to a service cell for hands-on inspection and seal and bolt replacement as necessary. The container seal surface is also inspected. Any containers or lids found to be defective are transferred to reprocessing maintenance cells for repair or disposal. 
Equipment Requirements :

2-ton bridge-mounted PAR manipulator.

Wal1-mounted manipulators (quantity to be determined).

Decontamination equipment.

Drying equipment.

Remote TV.

Container and lid support stands.

Container inspection equipment.

4.6. CONTAINER LOADING

Empty containers and $l i d s$ are received from refurbishing. If the container is to be returned empty to the reactor, the 1 id is put in place and it is moved to empty container storage or to the cask loading area. If the container is to carry refabricated fuel, it is moved to a loading station. Refabricated fuel elements in protective packaging are received from fuel element assembly. The fuel elements are loaded, five to a container. The fuel element serial numbers are recorded along with the container serial number. The closure is put in place and the container is leak checked. The loaded container weight is recorded along with its identification to form the fuel storage beginning inventory. The loaded container is transferred to fuel storage or cask loading, as appropriate. The container is marked to indicate further visual verification of correct customer batch. For fuel cycles using both U-233 and U-235 recycle elements, the container is marked to identify U-233 or U-235.

Reject refabricated fuel elements are loaded, six to a container. The containers are color-coded to avoid inadvertent shipment to a reactor and are stored in a special section of the storage facility. 


\section{Equipment Requirements :}

Two container loading stations and remote bolting/torquing equipment.

Container leak test equipment.

Remote TV.

2-ton bridge-mounted PAR manipulator and fuel grapple.

Wal1-mounted manipulator (quantity to be determined).

Container lid grapple.

Container paint marking device.

4.7. REFABRICATED FUEL STORAGE AND RETRIEVAL

Containers transferred from the loading station are identified and indexed to storage wells by customer batch. Reject-fuel containers are indexed to a special area for batch transfer to reprocessing when required. In the portable-well concept, the well is brought to the loading area, receives two containers, and is indexed back to its rack position. When containers are to be loaded for shipment, they are retrieved by customer batch and transferred to the cask loading area.

Equipment Requirements :

Two 5-ton-capacity bridge-mounted PAR manipulators with plug handling device and container grapple (plug-well storage).

Two 5-ton-capacity storage well transporters (portable-we11 storage).

Computer-controlled index device on fuel hand1ing mechanism. Remote TV. 
Container transfer mechanism for transfer of container from loading station to storage ( $p$ lug-well storage).

\subsection{CASK LOADING}

The cask is received from the spent fuel storage unloading area and is secured in place under the refabricated fuel loading port. A shielding collar is placed around the cask head and the port is opened. The temporary cask cover is removed. If the cask is to receive refabricated fuel, the cask is cooled by a portable cooling device so that the fuel protective packaging is not damaged. Loaded containers are weighed, identified, and placed in the cask. Information is recorded to establish shipper/receiver material balances and to close the storage material balance. Cask loads may consist partially of empty containers or may be entirely empty containers, since there is less refabricated fuel produced than spent fuel received. The cask closure is installed, and the cask is disengaged from the loading port, monitored, decontaminated as necessary, and moved to the service bay dispatching.

Equipment Required :

Cask cool-down system.

Cask loading port with shield cover.

Shielding collar.

Transfer car locks.

5-ton-capacity crane

2-ton-capacity PAR manipulator and grapple. 


\subsection{CASK DISPATCHING}

Before transfer to the service bay, the cask closure lifting gear is removed and the closure bolts are torqued. The cask closure is leak tested and the top impact limiter installed. The cask is removed from the transfer dolly by the 160-ton crane and transferred in a horizontal position to the transporter. The cask is tied down and radiation surveyed. The personnel barrier is installed, and the cask and transporter are released for shipment.

Equipment Required:

Rail car transfer engine. 160-ton-capacity crane, 30-ton hook. 5-ton-capacity crane.

closure seal testing equipment.

closure bolt pneumatic torquing equipment. Work platforms.
Can be same equipment as used for cask receiving. 


\section{FACILITY ARRANGEMENT CONCEPTS}

Facility arrangements for the plug-well concept and portable-well concept have been developed based on the functional requirement relationships described in section 4. The arrangements do not take into account structural considerations necessary to meet seismic requirements. The major structural constraints will probably be on the size of the pool and on the storage well design. Pool size requirements may result in a series of pool modules versus a single large pool for spent fuel and one for refabricated fuel. Previous studies (Ref, 3) have indicated that containers in wells may cause unacceptable stresses in the wells under assumed seismic conditions. The question of whether one- or two-container wells can be used also has an impact on pool size and configuration.

The assumptions for the two water-cooled storage concepts are discussed below, followed by a brief discussion of support services, including services necessary to allow the spent fuel storage facility to operate independently of the recycle plant.

\subsection{PLUG-WELL FACILITY ARRANGEMENT}

Figure 11 illustrates the plug-we11 arrangement in section view. A rail cask is shown at the loading port on its transfer car with the shielding collar in place. Spent fuel containers are transfered to holding wells by a PAR manipulator capable of weighing the loaded containers. They are picked up from the holding wells by a PAR manipulator equipped with a shield plug handling mechanism. The wells are loaded with two containers each. For retrieval, the containers are transferred to a rotating transfer mechanism that allows retrieval of the container in the opening and emptying cell. It can be seen from Fig. 11 that the 


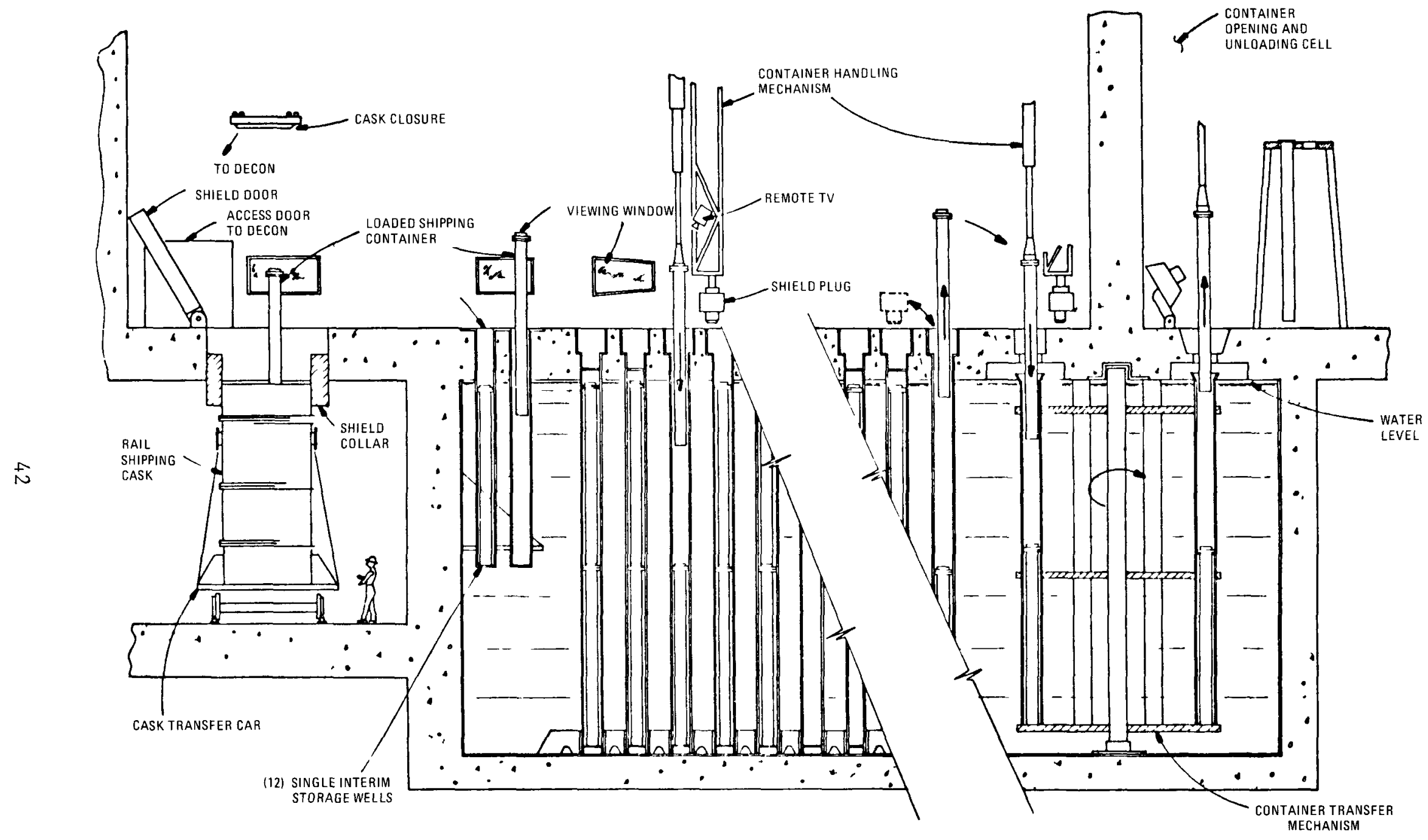

Fig. 11. Sectional elevation of plug-well storage concept - spent fuel 
storage wells and containers isolate the fuel from the water cooling medium. Fuel handling operations are fully remote, and personnel access to the area over the storage pool is not allowed. Cleanup of the air in the fuel handling cell, the cask unloading area, and the annulus over the pool water would require off-gas treatment, and a stainless steel pool liner would be required. The floor supporting the tops of the wells is required to be quite heavy. The refabricated fuel storage area is similar in arrangement except that it uses natural convection air cooling since the refabrication fuel heat load is low.

Figure 12 shows a suggested arrangement for the plug-well concept in plan view. Flow of material is from the cask unloading ports to the right of the control room, to the spent fuel storage area, and to the container opening cell where the fuel goes to the crusher. The container continues through the container decontamination cell, through drying and inspection, to storage. The container lid goes through the decontamination cel1, through the refurbishment service cell, to storage. As containers are needed, they enter the container loading cell and either receive refabricated fuel or reject fuel elements or are closed empty for return to the reactor. The containers go into refabricated fuel storage or directly to the temporary makeup wells to the left of the control room, for loading into casks at the loading ports to the left of the control room. Empty casks are moved from the spent fuel unloading ports to the refabricated fuel loading ports on the transfer car rails, which continue under the control room area. The arrangement shown facilitates material movement while meeting the requirement to keep spent fuel completely separated from refabricated fuel hand ing areas. 


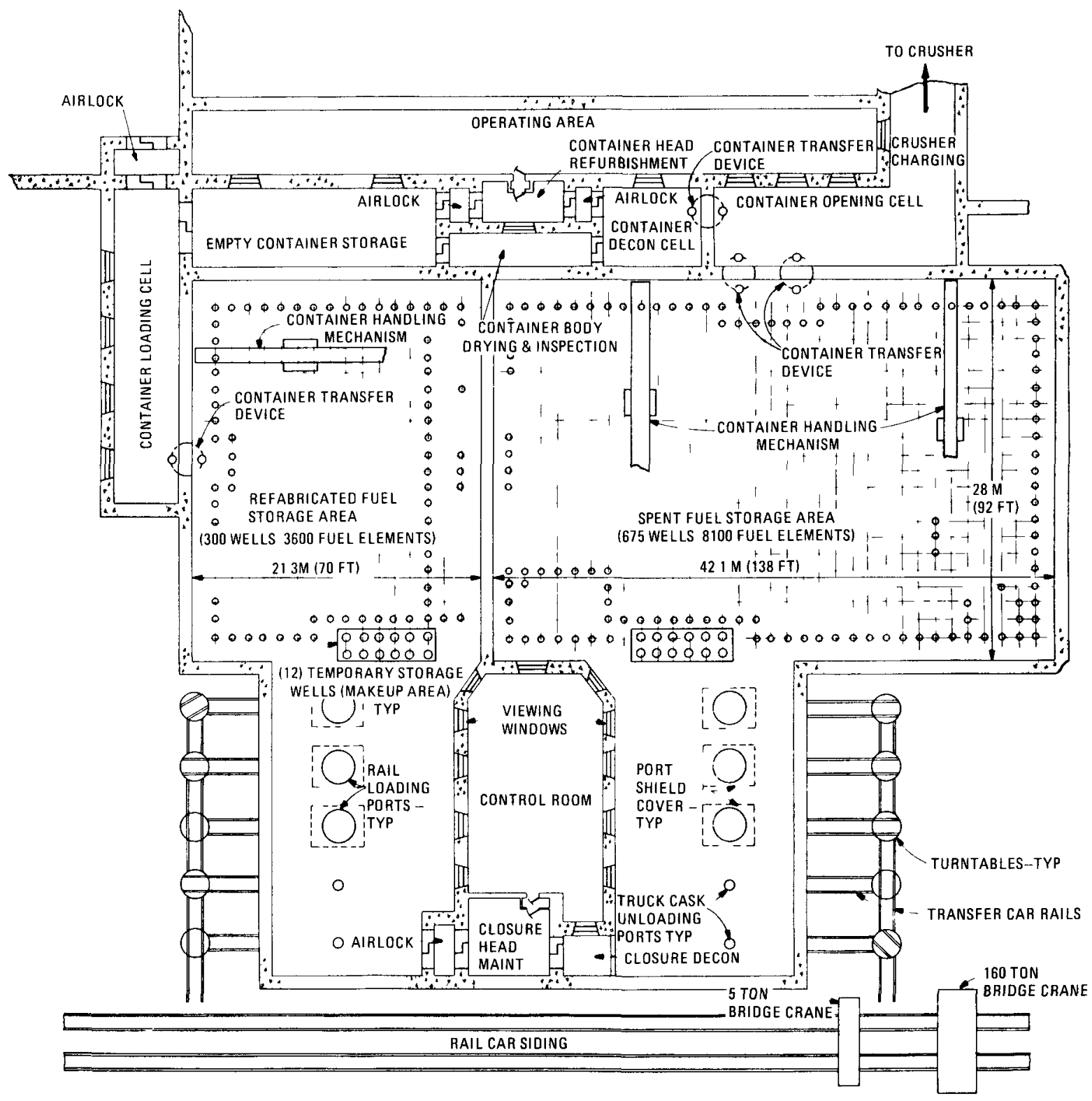

Fig. 12. Plan of receiving, storage, and shipping facility for plug-well concept 


\subsection{PORTABLE-WELL FACILITY ARRANGEMENT}

Figure 13 illustrates the portable-well arrangement in section view. In this concept, the storage wells are mounted in racks in the pool. They are removed by a storage well handling mechanism and placed in position below the unloading cell to receive two containers. They are then returned to position in the racks. For retrieval, the well is transported to a position below the container opening and emptying cell for removal of containers. This concept reduces the overhead handling space required and allows use of the space above the pool for other purposes. The volume of air requiring cleanup is reduced. Double containment of the fuel to isolate it from water is provided as in the plugwell concept. A stainless steel pool liner is also required in this concept, but the floor over the pool can be lighter as it is not supporting the weight of the wells.

Some economy of spacing the wells can be realized. The plan view in Fig. 14 indicates that the same number of fuel elements can be stored in about 16,000 square feet as opposed to 19,000 square feet shown for the plug-well concept in Fig. 11. It should be emphasized, however, that differences in structural requirements for the two concepts could negate this benefit.

The flow of materials is the same in the portable-well concept as in the plug-well.

\subsection{SUPPORT SERVICE ARRANGEMENT}

The storage facility integral to a recycle plant as shown in Figs. 12 and 14 has numerous support service requirements, many of which are handled by the recycle plant itself. If the support facility is to be 


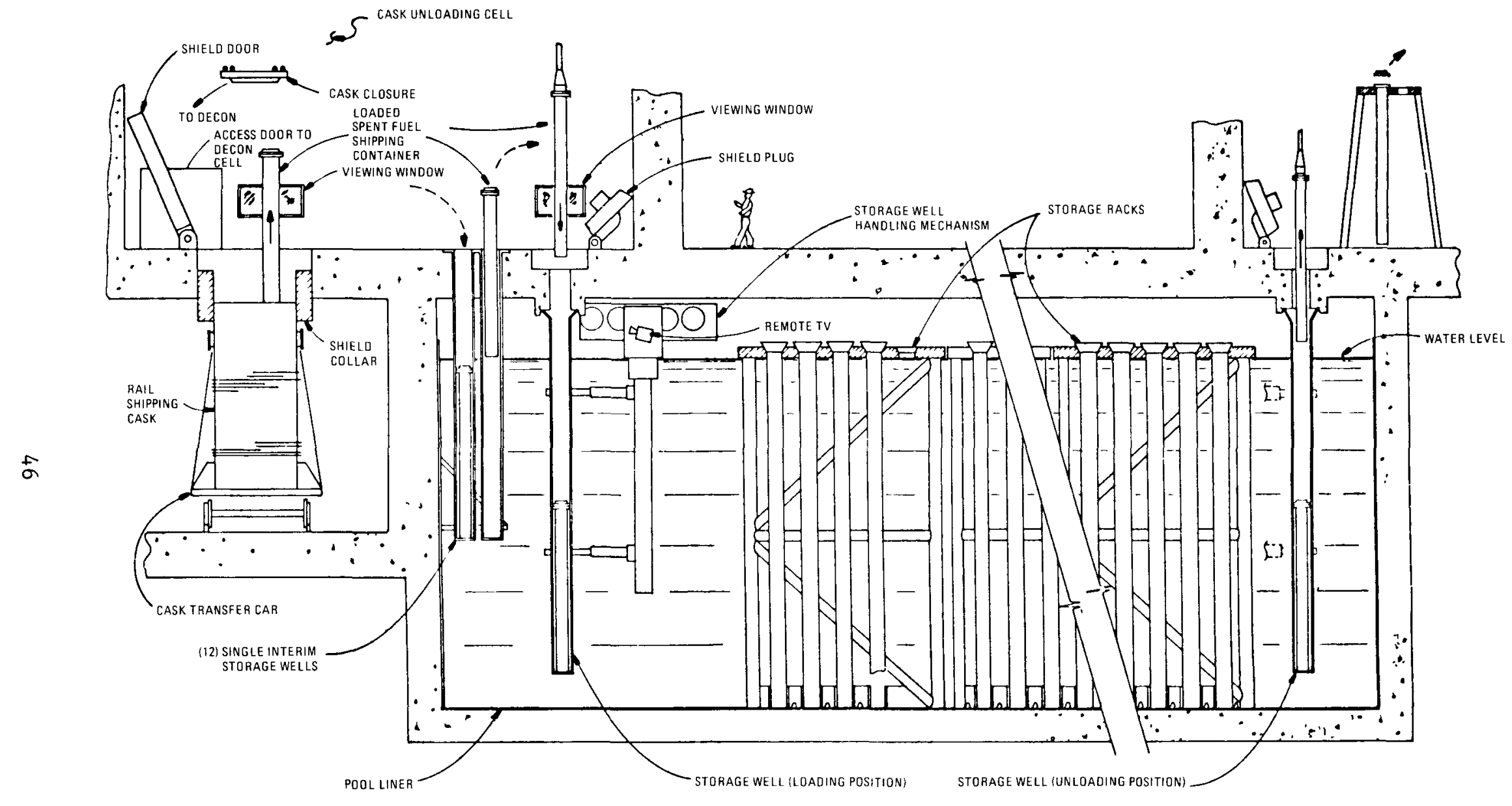

Fig. 13. Section elevation of portable-well storage concept 


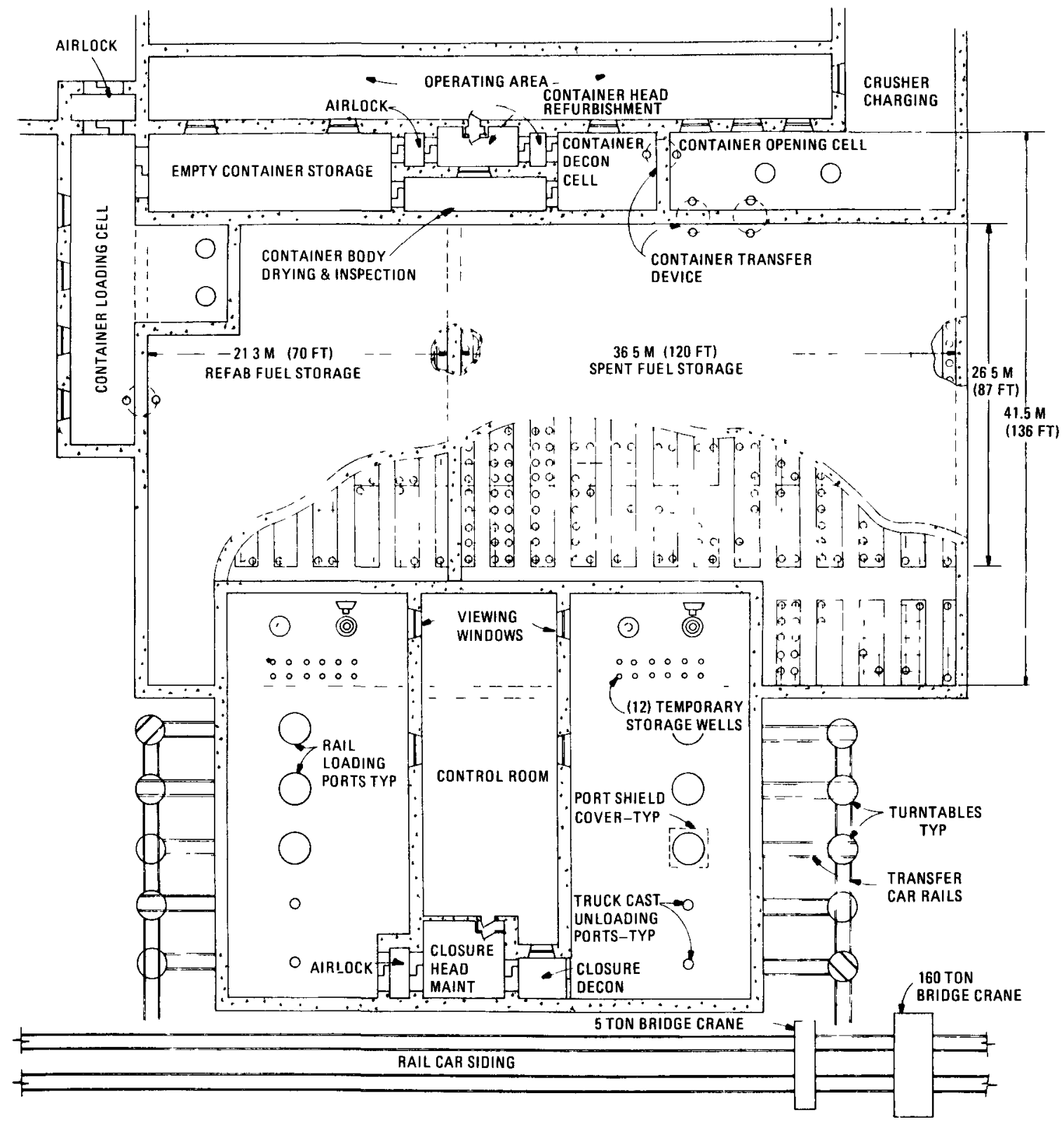

Fig. 14. Plan of receiving, storage, and shipping facility arrangement rack portable-well concept 
self-supporting to provide interim service until a recycle plant is built, support service arrangements have to be considered in the storage facility layout itself. The assumptions for both cases are discussed briefly below.

\subsubsection{Support Services for Integral Plant}

While the arrangements shown in Figs, 12 and 14 facilitate the flow of material within the storage facility, support services received from the reprocessing facility also have a bearing on the arrangement (as will the feed point to reprocessing and the receiving point from refabrication).

Since all equipment in the storage facility is serviced by the recycle plant maintenance cells, access for transfer of the equipment must be provided. Access for transfer of solid waste, such as used seals, must also be provided.

The pool water must be accessible to the liquid waste treatment system. A water cleanup system is dedicated to the storage pool as shown in Fig. 15; however, treatment is for chemical control only. Access to the liquid waste treatment must be provided for radioactive effluent cleanup should the water become contaiminated due to leaking or ruptured containers and storage wells under accident conditions.

Air in container handling areas and the space above the pool water must be controlled for any required treatment before release to the stack. Due to the containerized fuel concept, air contamination is minimal. A recirculating system can be used, and air cleanup can be accomplished periodically through the secondary burner off-gas system when the burners are not in operation. This ideally requires proximity to the burner off-gas treatment system. 


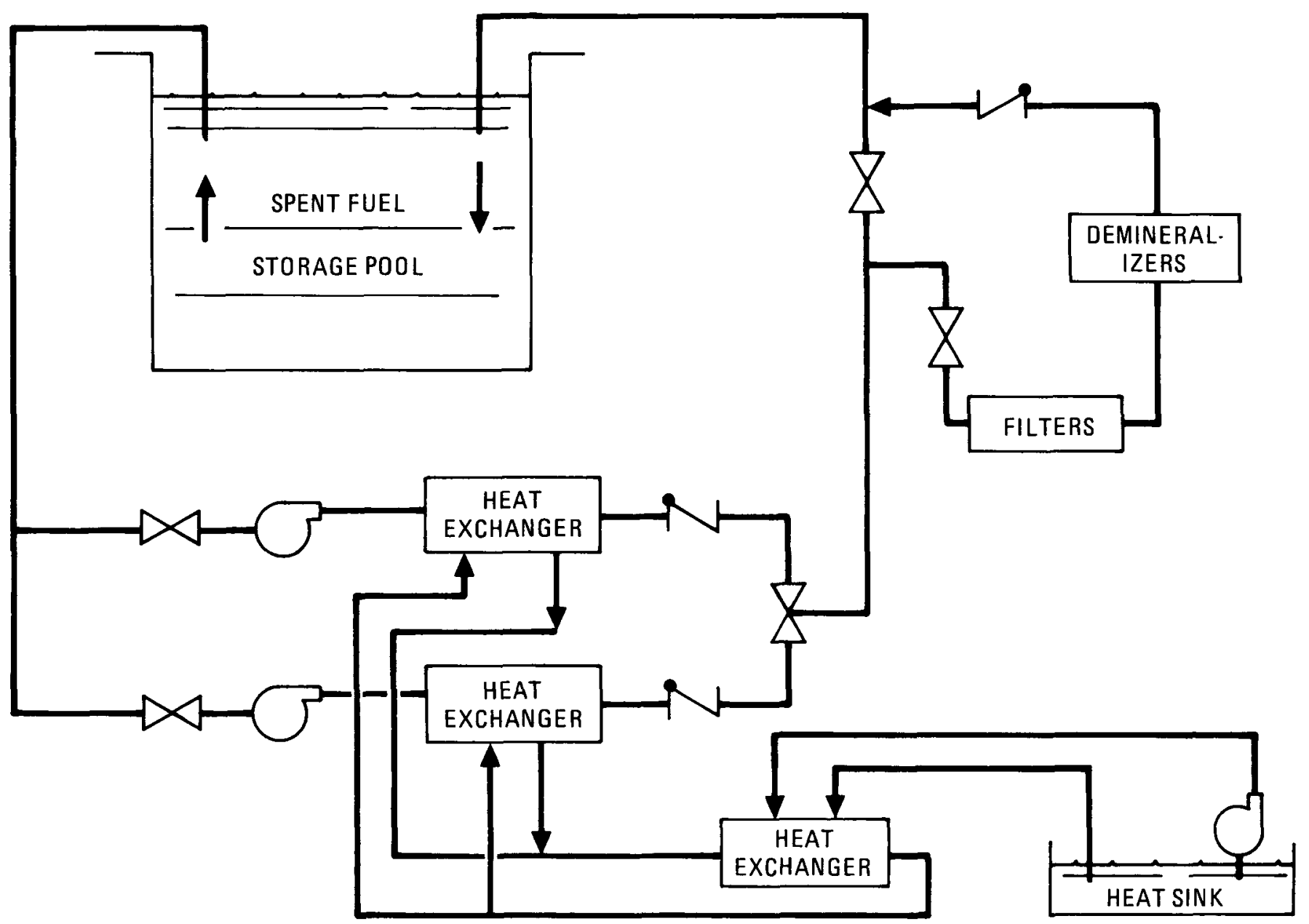

Fig. 15. Spent fuel pool cooling and cleanup system 
Additional services received from the recycle plant include:

1. Chemical makeup and storage for water treatment.

2. Spare equipment and parts storage.

3. Laundry, change areas, and cafeteria.

4. Emergency utilities.

5. Sewage treatment.

6. Water and power supplies.

7. Heating, ventilating, and air conditioning.

8. Administrative services such as payrol1, accounting, and personnel .

9. Rail yards and roads (including a yard locomotive).

10. Analytical laboratory services (cold laboratory for health physics and environmental samples and for water and off-gas samples).

11. Fire protection.

12. Security services (guard service, perimeter protection, badges, and TV monitoring).

13. Health physics and medical services. 


\subsubsection{Support Services for Stand-Alone Facility}

If a spent fuel storage facility is built to handle interim storage of fuel while the recycle plant is being built, or even in advance of recycle plant construction, a different facility arrangement would be required to accommodate the support services enumerated in Section 5.3.1. One possibility would include construction of the refabricated fuel storage and handling building shell and use of the space for temporary service installations. Trailers could also be used for temporary administration and cafeteria services. Partial capacity for water and power supply for the future recycle plant could be installed, as could partial rail yards and road systems. Economic tradeoffs would have to be analyzed to determine the cost of providing services in temporary quarters that would require dismantling versus building recycle plant service systems early.

Since the storage facility arrangement shown in Figs. 12 and 14 only provides 90-day surge for the recycle plant, a stand-alone facility would be much larger unless there were a very slow market buildup followed by several reactors on line at the same time to justify a recycle plant. 


\section{DEVELOPMENT REQUIREMENTS}

The use of water-cooled concepts allows taking advantage of a we11developed technology. Significant design issues that require further definition, resolution, or demonstration are summarized below.

\subsection{STRUCTURAL AND SEISMIC ANALYSIS}

Acceptable structural arrangements to meet seismic criteria must be developed. This includes evaluating the maximum pool size and wall thicknesses. A method of restraining storage canisters must be determined. Particularly, the effects of two containers per storage well must be evaluated. In the rack-mounted well concept, methods of restraining racks and maximum rack size must be determined.

\subsection{DAMAGED FUEL ELEMENTS AND CONTAINERS}

The capability to remotely remove and handle damaged or broken fuel elements from containers that may also be damaged must be demonstrated. Since this is done in remote maintenance in the reprocessing plant, it could include cutting the container.

\subsection{REMOTE HANDLING AND MAINTENANCE}

The capability to perform remote retrieval, maintenance, and disassembly of fuel and container handling equipment must be demonstrated. 
6.4. SPENT FUEL TRANSFER TO HEAD END

The capability to remotely empty the shipping containers and feed the contents to the fuel element crusher must be demonstrated. 
1. "Conceptual Design Summary and Design Qualifications for HTGR Target Recycle Plant," ERDA Report GA-A13365, General Atomic Company, May 1975.

2. Reeser, H. G., "High Temperature Gas-Cooled Reactor Spent and Recycle Fuel Shipping," paper presented at American Power Conference, Chicago, I1linois, Apri1 21-23, 1975.

3. "HTGR Reactor Service Building Alternate Fuel Handling and Storage Study-3,000 MW( $t$ ) Reference Plant," NSS-8200.1, Nuclear and Systems Sciences Group, Holmes and Narver, Inc., August 1974.

4. "National Program Plan for HTGR Fuel Recycle Development," GCR76/19, Oak Ridge National Laboratory, October 1977.

5. Holder, N., General Atomic Company unpublished data, January 1974.

6. Borgonovi, G. M., "Computer Simulation of HTGR Fuel Transportation and Recycling," General Atomic Report GA-A13757, November 1975.

7. Reeser, H. G., General Atomic Company unpublished data, January 1975. 